\title{
Diagnostic Systems Approach to Watershed Management
}

\author{
M.L. Davisson
}

February 23, 2001 


\section{DISCLAIMER}

This document was prepared as an account of work sponsored by an agency of the United States Government. Neither the United States Government nor the University of California nor any of their employees, makes any warranty, express or implied, or assumes any legal liability or responsibility for the accuracy, completeness, or usefulness of any information, apparatus, product, or process disclosed, or represents that its use would not infringe privately owned rights. Reference herein to any specific commercial product, process, or service by trade name, trademark, manufacturer, or otherwise, does not necessarily constitute or imply its endorsement, recommendation, or favoring by the United States Government or the University of California. The views and opinions of authors expressed herein do not necessarily state or reflect those of the United States Government or the University of California, and shall not be used for advertising or product endorsement purposes.

This work was performed under the auspices of the U. S. Department of Energy by the University of California, Lawrence Livermore National Laboratory under Contract No. W-7405-Eng-48.

This report has been reproduced

directly from the best available copy.

Available to DOE and DOE contractors from the

Office of Scientific and Technical Information

P.O. Box 62, Oak Ridge, TN 37831

Prices available from (423) 576-8401

http://apollo.osti.gov/bridge/

Available to the public from the National Technical Information Service

U.S. Department of Commerce 5285 Port Royal Rd., Springfield, VA 22161 http://www.ntis.gov/

OR

Lawrence Livermore National Laboratory Technical Information Department's Digital Library http://www.llnl.gov/tid/Library.html 


\title{
Diagnostic Systems Approach to Watershed Management
}

\author{
M. Lee Davisson \\ Health and Ecological Assessment Division \\ Energy and Environment Directorate \\ LDRD FY98-ERD-046 Final Report
}




\section{Abstract}

The water quality of discharge from the surface water system is ultimately dictated by landuse and climate within the watershed. Water quality has vastly improved from point source reduction measures, yet, non-point source pollutants continue to rise. 30 to $40 \%$ of rivers still do not meet water quality standards for reasons that include impact from urban storm water runoff, agricultural and livestock runoff, and loss of wetlands. Regulating non-point source pollutants proves to be difficult since specific dischargers are difficult to identify. However, parameters such as dissolved organic carbon (DOC) limit the amounts of chlorination due to simultaneous disinfection by-product formation.

The concept of watershed management has gained much ground over the years as a means to resolve non-point source problems. Under this management scheme stakeholders in a watershed collectively agree to the nature and extent of non-point sources, determine water quality causes using sound scientific approaches, and together develop and implement a corrective plan. However, the "science" of watershed management currently has several shortcomings according to a recent National Research Council report. The scientific component of watershed management depends on acquiring knowledge that links water quality sources with geographic regions. However, there is an observational gap in this knowledge. In particular, almost all the water quality data that exists at a utility are of high frequency collected at a single point over a long period of time. Water quality data for utility purposes are rarely collected over an entire watershed. The potential is high, however, for various utilities in a single watershed to share and integrate water quality data, but no regulatory incentives exist at this point. The only other available water quality data originate from special scientific studies. 
Unfortunately these data rarely have long-term records and are usually tailored to address unrelated research questions. The goal of this research was to investigate whether scientific research tools were available that could provide evidence that links water quality and land type. In particular, could such tools be used on raw water at the treatment point rather than monitoring over a large geographic spanning a watershed.

This report summarizes the utility of using isotopic tracers to better understand sources of non-point source pollution and their relation to industry standard water quality measurements.

In this study we have found that much of the water quality data generated by utilities is under-interpreted in the context of understanding watershed processes. For example, the City of St. Louis depends solely on the Missouri River for drinking water, but due to large variability in discharge and runoff sources, they are faced with DOC concentrations that vary nearly a factor of three within a single season. The relationship between discharge and concentration has not been constrained. However, we found a linear correlation between the DOC concentration and the fractional amount of downstream discharge (derived from within the State of Missouri). This correlation relates directly to differences in land use and climate between the upstream and downstream portions of the river basin.

In addition to using utility water quality data to better understand non-point source pollutants, non-regulatory type data can be generated to enhance observational knowledge. Data such as isotopic measurements of water and dissolved constituents can provide indirect evidence for sources and the processes governing the occurrence and concentration of non-point source pollutants. For example, using isotope measurements 
of carbon-13 on DOC in the Missouri River, we were able to distinguish carbon originating from algae photosynthesis versus that generated from land plant material. Their relative proportions correlated with season and water temperature. We also found that the carbon-14 abundance of DOC decreased with increasing humic material, indicating that at various times DOC comprises older sources of carbon. Humic material also preferentially forms tri-halomethanes during chlorination, relative to the remaining portion of DOC. The carbon-14 abundance of humic isolates showed a strong inverse correlation to electrical conductivity. This relationship provided a basis to delineate the geographic source of the DOC. In addition, the carbon-14 of humic isolates from several rivers located in the western hemisphere, representing different climates, positively correlated with mean annual precipitation, indicating a strong relationship between solublization rates of soil carbon and regional climate. This may provide a predictive basis for humic sources in watersheds similar to the Missouri River.

\section{Introduction}

Roughly half the domestic drinking water supplies in the United States originate from direct treatment of surface water. A surface water system is defined by its watershed, which is an area constrained by topographic boundaries, and all stream flow converges at a single point within those boundaries. The water quality of discharge from the surface water system is ultimately dictated by landuse and climate within the watershed. Before approximately 1980, point source discharge from industry and urban waste threatened drinking water quality and its treatability in many lakes and rivers. Water quality has vastly improved from point source reduction measures, yet, non-point source pollutants 
continue to rise. One of the major non-point source pollutants of concern is water-borne pathogens, and of equal concern are the risks associated with pathogen disinfection and formation of potentially hazardous byproducts. This has lead to the promulgation of the Information Collection Rule, and ultimately the implementation of the DisinfectantsDisinfection By-Product Rule. The extent of pathogen occurrence combined with the total organic carbon (TOC) concentration and its reactivity during disinfection will determine the extent of regulation and treatment schemes.

The rising problem of industrial and urban waste water discharge to rivers in the US during the mid-1900s sparked the need to regulate point-source pollution discharge. This gave rise to enactment of the Clean Water Act in 1972, which over the past $\sim 30$ years resulted in $98 \%$ reduction in metals and organics according to the USEPA. Today 60 to $70 \%$ of surface water currently meets quality standards. Much of this has been accomplished by implementing a permitting process for point source discharge, which required public financing of waste water treatment facilities and use of best available technology. However, 30 to $40 \%$ of rivers still do not meet water quality standards for reasons that include impact from urban storm water runoff, agricultural and livestock runoff, and loss of wetlands. These causes differ from those responsible for poor water quality prior to 1972 , in that they are generated for the most part by non-point sources and land use changes.

Non-point source pollution results from specific land types or land use activities, which can create pollutant loads of a moderate to low level, but which occur over large geographic areas and have a cumulative effect. For example, agricultural areas of the midwestern states within the Mississippi River drainage are thought to contribute the bulk 
of the annual nitrogen loads transported out to the Caribbean Sea, and are thought to be responsible for a growing anoxia problem (Goolsby et al., 2000). A more chronic problem for the drinking water community is the persistent and increasing occurrence of pathogens in raw drinking water, which requires extensive oxidative or chlorinated treatment. However, parameters such as dissolved organic carbon (DOC) limit the amounts of chlorination due to simultaneous disinfection by-product formation.

Regulating non-point source pollutants proves to be difficult since specific dischargers are difficult to identify. More recent amendments to the CWA (section 319) in 1987 provides a regulatory basis to address non-point source pollution. However, processes generating non-point source pollutants are not well understood or are controversial, and typically they are poorly constrained geographically.

The concept of watershed management has gained much ground over the years as a means to resolve non-point source problems. Under this management scheme stakeholders in a watershed collectively agree to the nature and extent of non-point sources, determine water quality causes using sound scientific approaches, and together develop and implement a corrective plan. However, the "science" of watershed management currently has several shortcomings according to a recent National Research Council report (NRC, 1999). Among them is a lack of interdisciplinary science approaches conducted at appropriate spatial and temporal scales that could be used to facilitate decision-making within a watershed management framework. Consequently, much of the regulatory focus is still at the point of treatment.

A good example of the current focus at the treatment point includes the rising concern over pathogen occurrence in raw drinking water. This has promulgated the proposed 
regulatory framework of microbial/disinfectant and disinfection byproduct rules. The initial concern was actually health effects associated with disinfection byproduct formation during chlorination, but outbreaks of pathogens such as Cryptospiridium in public drinking water broaden the scope to microbial reduction. The rule-making process is incremental beginning with the Information Collection Rule (ICR). This required major utilities to collect 18 months of water quality data for microbial and disinfection byproduct occurrences. The next incremental action is the formation of a formal advisory committee to assess the data collected under the ICR, and the available health affects data and attempt to agree on regulation guidelines. Possible guidelines may include alternate oxidative treatment methods such as ozonation, utilization of membrane filtration steps, better source water protection, and reduction of total organic matter concentrations before chlorination. All of these outcomes equate to increased costs at the point of treatment. However, some of these costs could be offset if utilities better understood the watershed processes controlling water quality at the treatment point. This better understanding could at least enhance the predictability of time periods where poorer water quality occurs and allow flexibility in daily operational procedures and reduce annual costs.

The scientific component of watershed management depends on acquiring knowledge that links water quality sources with geographic regions. However, there is an observational gap in this knowledge. In particular, almost all the water quality data that exists at a utility are of high frequency collected at a single point over a long period of time. Water quality data for utility purposes are rarely collected over an entire watershed. The potential is high, however, for various utilities in a single watershed to share and integrate water quality data, but no regulatory incentives exist at this point. The only 
other available water quality data originate from special scientific studies. Unfortunately these data rarely have long-term records and are usually tailored to address unrelated research questions. The goal of this research was to investigate whether scientific research tools were available that could provide evidence that links water quality and land type. In particular, could such tools be used on raw water at the treatment point rather than monitoring over a large geographic spanning a watershed. This report summarizes the utility of using isotopic tracers to better understand sources of non-point source pollution and their relation to industry standard water quality measurements.

In this study we have found that much of the water quality data generated by utilities is under-interpreted in the context of understanding watershed processes. For example, the City of St. Louis depends solely on the Missouri River for drinking water, but due to large variability in discharge and runoff sources, they are faced with TOC concentrations that vary nearly a factor of three within a single season. The relationship between discharge and concentration has not been constrained. However, we found a linear correlation between the TOC concentration and the fractional amount of downstream discharge (derived from within the State of Missouri). This correlation relates directly to differences in land use and climate between the upstream and downstream portions of the river basin.

In addition to using utility water quality data to better understand non-point source pollutants, non-regulatory type data can be generated to enhance observational knowledge. Data such as isotopic measurements of water and dissolved constituents can provide indirect evidence for sources and the processes governing the occurrence and concentration of non-point source pollutants. For example, using isotope measurements 
of carbon-13 in DOC in the Missouri River, carbon originating from algae photosynthesis could be distinguished that generated from land plant material. Their relative proportions correlated with season and water temperature. We also found that the carbon-14 abundance of DOC decreased with increasing humic material, indicating that at various times DOC comprises older sources of carbon. Humic material also preferentially forms tri-halomethanes during chlorination, relative to the remaining portion of DOC. The carbon-14 abundance of humic material also showed a strong inverse correlation to electrical conductivity. This relationship provided a basis to delineate the geographic source of the DOC. In addition, the carbon-14 of humic material from several rivers located in the western hemisphere, representing different climates, positively correlated with mean annual precipitation, indicating a strong relationship between solublization rates of soil carbon and regional climate. This could provide a predictive basis for humic sources in watersheds similar to the Missouri River.

\section{Experimental Background and Methods}

$\underline{\text { Stable Isotope Tracers of Surface Water }}$

The isotopic fractionation of $\delta^{18} \mathrm{O}$ and $\delta \mathrm{D}$ values in natural water is ultimately governed by the temperature during water evaporation and condensation. As such, large isotopic variations are observed geographically as a function of latitude and altitude (e.g. Epstein and Mayeda, 1953; Craig, 1961; Dansgaard, 1964). Storm systems migrating over the continent are essentially closed hydrologic systems. Sequential loss of cloud water with time in these storm systems, combined with isotopic fractionation, cause an isotopic distillation effect. Therefore, during continental migration of storm tracks, 
heavier isotopes become preferentially depleted in precipitation with distance and time (Fig. 1; e.g. Dansgaard, 1964; Sheppard, 1986).

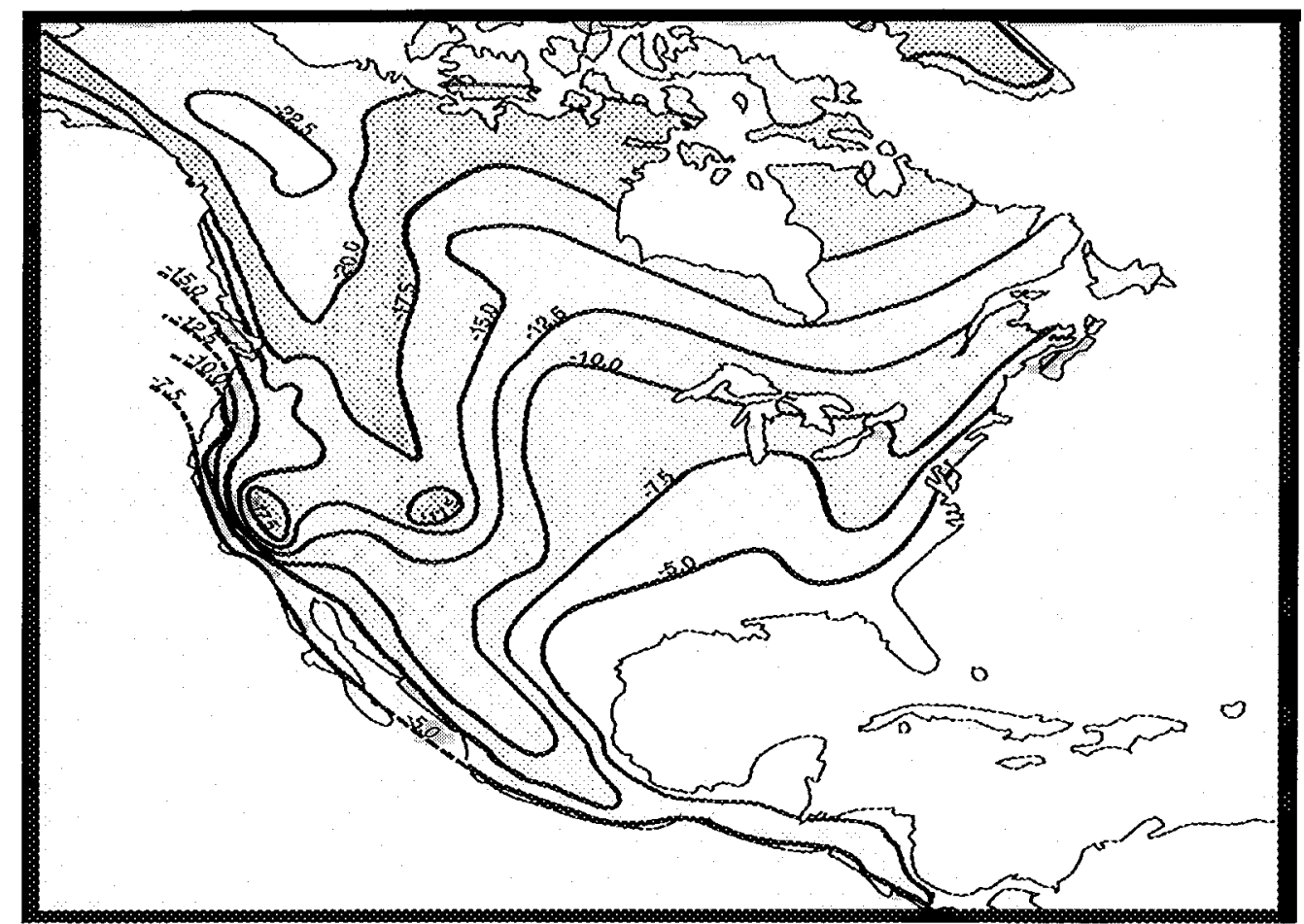

Figure 1. Mean annual $\delta^{18} \mathrm{O}$ values for surface water and precipitation in North America is controlled by latitude, elevation, and distance from coastal areas (after Taylor, 1974)

The global meteoric water line (MWL) of $\delta \mathrm{D}=8 \delta^{18} \mathrm{O}+10$ (Craig, 1961) reflects the isotopic abundance of water vapor condensed under isotopic equilibrium at different temperatures, and/or during progress of the distillation effect in single storm systems. The slope, and the y-intercept (i.e. deuterium excess), results, respectively, from the relative fractionation of $\mathrm{D} / \mathrm{H}$ and ${ }^{18} \mathrm{O} /{ }^{16} \mathrm{O}$ between water liquid and vapor, and from kinetic isotope fractionation between water and water-vapor evolving over the open ocean (Craig and Gordon, 1965). Continental surface water and shallow groundwater also undergoes kinetic isotope enrichment during evaporation, and liquid water isotopic 
values enrich along trajectories with slopes between 2.0 and 6.0 on a $\delta \mathrm{D}-\delta^{18} \mathrm{O}$ plot (Craig et al., 1963; Stewart, 1975; Barnes and Allison, 1988).

The continental variation in $\delta \mathrm{D}$ and $\delta^{18} \mathrm{O}$ values are reflected strongly in river water (Friedman et al., 1964; Ramesh and Sarin, 1992). For example, large river systems, such as the Missouri River, originate in high elevation regions of the eastern Rocky Mountains, where melting snow contributes runoff with low deuterium and ${ }^{18} \mathrm{O}$ abundances, whereas lower elevation watersheds in Nebraska, Kansas, and Missouri contribute runoff to the Missouri with higher isotopic abundances. Although interseasonal variations in the mean isotopic value can occur (Friedman and Smith, 1972; Criss et al., 2001), the large spatial variations in source areas in river systems dominates the isotopic signature.

Isotopic abundances of deuterium and ${ }^{18} \mathrm{O}$ can vary significantly between and within different storm events, and appears to be related to mean air temperatures during the storm and storm sources (Friedman et al., 1964; Lawrence et al., 1981). These inter-storm variations have been exploited in small watershed studies to delineate groundwatersurface water interaction in stream runoff (Sklash and Farvolder, 1979; Pionke et al., 1993; Fredrickson and Criss, 1999). Because groundwater tends to homogenize the interstorm isotopic variability, its contribution to stream flow will be distinguishable from surface runoff originating from a single storm. This dynamic relationship has recently been exploited as a groundwater dating tool (Fredrickson and Criss, 1999).

Since water evaporation preferentially enriches the liquid phase in both deuterium and ${ }^{18} \mathrm{O}$, a good linearity exists between salinity and isotopic abundance (Friedman et al., 1964; Craig and Gordon, 1965). This relationship can be used to trace sources of salinity 
in surface and ground water investigations (Payne et al., 1979; Simpson and Herzeg, 1991; Lambs, 2000; Criss et al., 2001).

\section{Tracing Dissolved Organic Matter in Surface Water}

\section{Introduction}

Interest in understanding the sources and character of natural organic matter spans nearly 200 years, with concerted efforts to isolate and chemically characterize its nature beginning in the early 1900's (see Stevenson, 1985 for history of soil organic matter, and Thurman, 1985 or Malcolm, 1985 for history of aquatic organic matter). The amount of organic carbon in rivers became a major concern later when industrial effluents and raw sewage that discharged into rivers and lakes contributed to high BOD and oxygen sag. More recent water quality interest in dissolved organic matter is associated with drinking water chlorination and the formation potential of disinfection by-products (e.g. Rook, 1977, Larson and Webber, 1994, Singer, 1999).

Parallel research divorced of drinking water quality interests has existed in ecosystem and climate studies. Here much of the research has focused on the role of aquatic organic matter as a base nutrient in food chains (e.g. Munster and Chrost, 1990), global fluxes with respect to the carbon cycle (see Schlesinger, 1994), and its rate of turnover in terrestrial ecosystems (e.g. Hedges et al., 1986). These research areas in many respects pursue similar questions regarding source and character of organic matter as in the water quality field, but have no traditional overlap.

One necessary digression at this point requires review of terminology used for organic matter. In the natural sciences, aquatic organic matter is usually separated into three 
fractions. These include 1) dissolved organic matter (DOC), which is organic matter that passes through a $0.45 \mu \mathrm{m}$ filter, 2) particulate organic matter (POC), which is retained by the $0.45 \mu \mathrm{m}$ filter and has been referred to also as suspended organic matter, and 3) total organic matter (TOC), which is the sum of the DOC and POC. In the drinking water quality field there has been traditional use of the term TOC for measurements of surface water filtered at $0.45 \mu \mathrm{m}$. However, technically the measurement is DOC, but since many rivers and streams comprise mostly $<0.45 \mu \mathrm{m}$ organic material, the terminology has been freely interchanged. The reader is referred to Thurman (1985) for further discussion. This report will use, whenever possible, DOC.

\section{DOC Concentrations}

Thurman (1985) summarized the DOC concentration in world rivers, showing the highest concentrations were in wetlands and swamps (avg. $25 \mathrm{mg} / \mathrm{L}$ ), the lowest in arctic, alpine, and arid regions (avg. 2-3 mg/L), and temperate to tropical climates were in between (avg. 3-7 mg/L). Climate is one of the most important factors controlling DOC concentration in rivers (Thurman, 1985). Annual precipitation and temperature independently control terrestrial climate and vegetation in a watershed. Their correlation to net primary productivity (NPP) of vegetation has long been established (see e.g. Schlesinger, 1996). Areas of high precipitation rates, temperatures, and NPP (i.e. tropics) typically have extensively weathered soils somewhat poor in organic matter, and their associated rivers typically have high DOC. In contrast, regions with lower NPP (e.g. prairies) typically have less weathered soil, but with a higher organic carbon sequestering capacity. Consequently, rivers in more arid climates tend to have lower DOC. High 
dissolved solids are typical for river waters in semi-arid to arid regions, whereas low dissolved solids are common in temperate woodland, alpine, and tropical rivers. Tropical soils are typically devoid of divalent cations, and hence humic substances comprising DOC are more readily soluble (see e.g. Hayes and Swift, 1978). This also is consistent with observations of Aiken and Malcolm (1987), who showed that DOC concentrations and the molecular weights of their humic substances (see below) were inversely proportional to the dissolved solid concentration of the surface waters. They similarly concluded that more weathered soils have fewer divalent cations and produce dissolved humic substances with higher solubilities and higher molecular weights.

Within river systems different vegetation types and microclimates can control DOC concentrations. For example, in southeastern US lowland areas comprising wetland settings produce significantly higher DOC than upland forested areas (e.g. Mulholland and Kuenzler, 1979). Wetlands typically have high carbon fixation rates and are known to discharge water with high DOC concentrations (e.g. Mann and Wetzel, 1995). In the Missouri River, annual precipitation is twice as high in the lower river area than in the upper watershed (see below).

Podzolization of soil with depth has been shown to increase sequestration of leached soil organic from shallow zones, which subsequently affect stream DOC concentration (McDowell and Wood, 1984). Soil formation in different geologic rock types can have a significant effect of organic carbon sorption and DOC concentrations in adjacent streams (Nelson et al., 1993). More recent work has shown that soil mineralogy also plays an important role in cycling rates of soil organic matter (Torn, et al., 1997). 
During storm flow, DOC concentration in a river typically rises. Studies attribute this rise to flushing of DOC-rich soil water and leaching of leaf litter from runoff and throughflow (e.g. Brinson, 1976; Thurman, 1985; Fiebig et al., 1990).

Lastly, storage of river water in large reservoirs, effluent from agricultural irrigation, and treatment through artificial wetlands can all have significant effects on the DOC concentration, including increased POC from algae and higher disinfection byproduct formation (e.g. Amy et al., 1990; Parks and Baker, 1997)

\section{DOC Characterization}

Aside from bulk concentration measurements, a rich and diverse history of DOC characterization exists in the open literature. Much of this previous work is outside the scope of this report, but a brief summary is provided. Probably the most relevant feature of DOC characterization to this report is the distinction between allochthonous and autochthonous sources (see Thurman, 1985). Allochthonous DOC is derived from plant and soil sources, or outside the aquatic environment, whereas autochthonous DOC is generated within the water column. For example, autotrophs, such as algae, would be the most common autochthonous source of POC and DOC, whose amount varies depending on the aquatic system and season. Most river environments are dominated by allochthonous DOC because of adjacent soils and vegetation. However, where natural or man-made lakes and reservoirs are present, autotrophic contribution to the DOC pool can increase, particularly where nutrient levels are high. Typical algal production can vary in lakes depending on latitude, climate, lake depths, clarity and nutrient levels. For example, mid-latitude lakes $\left(39-55^{\circ} \mathrm{N}\right.$ ) have photosynthetic fixation rates up to $2 \mathrm{gC} / \mathrm{m}^{2}$-day in mid- 
summer, whereas they will be nearly 10 times lower in winter, while equatorial lakes show little seasonal variation but have high photosynthetic fixation rates (e.g. $5 \mathrm{gC} / \mathrm{m}^{2}-$ day; Tilzer, 1987). The distribution of allochthonous and autochthonous sources of DOC in rivers will in general be dictated by the amount of algal productivity within the flowing water, the number and character of surface impoundments contributing to the flow, latitude, and the season.

Besides allochthonous and autochthonous forms of DOC, its character can also be delineated based on compound identification, chemical function, acidity, and solubility. The most rigorous attempts to identify chemical compounds have resulted in about 85$90 \%$ of the DOC unidentifiable (e.g. Ding et al., 1996). In natural waters identifiable compounds typically are mono- and polysaccharides, amino acids, pigments such as chlorophyll $a$, and short-chained carboxylic acids (Lytle and Perdue, 1981; Sweet and Perdue, 1982; Thurman, 1985). In soil science, base extraction of organic matter followed by a strong acid always resulted in precipitation of humic acid (Stevenson, 1985). These are non-polymeric phenolic compounds with molecular weight between 500-1000 Daltons. They have low solubility, and therefore their common association with soils. They likely are mostly organic residues of chemical and microbial decay of plant material.

Many spectroscopy methods are available to characterized DOC by functional groups. For many years researchers struggled with isolation and purification of DOC. Unfortunately, loss due to either sorptive media or during desalting by ion exchange always resulted in preferential loss. Nevertheless, early work did much to identify many functions of the unidentifiable portion of DOC as acidic carboxylic, hydroxyl, ketone 
groups, as would be expected for oxidized waters. The development and use of non-ionic resins in the late 1970's did much to advance the field of isolation and characterization, and resulted a general operational class of organic isolates (Thurman and Malcolm, 1981; Aiken et al., 1994). XAD-8 and XAD-4 are commonly employed by researchers today to isolate and purify DOC into humic and hydrophilic substances, respectively. Humic substances extracted from water can be separated into humic and fulvic acid upon acidification. The humic substances tend to be aromatic rich, with aliphatic linkages (Malcolm, 1985). Hydrophilic substances tend to be more carbohydrate rich, and have density of oxidized functional groups (Aiken et al., 1994). XAD-8 and XAD-4 do not isolate all the DOC, for which some passes through. Higher conductivity water tends to have poor yields on the resins. Recent advancements to these isolation techniques have achieved $100 \%$ recoveries of DOC into purified isolates (Leenheer et al. 2000).

\section{Isotopic Studies of Dissolved Organic Matter}

Isotopic studies of DOC have been surprisingly limited. Most isotopic data for aquatic organic matter has been conducted on POC. For example, previous observation of $\delta^{13} \mathrm{C}$ values measured on aquatic organic matter in rivers of particular note was the work of Bird et al. (1998) who showed annual $\delta^{13} \mathrm{C}$ variations (up to 6.0 per mil) in POC of river Sanaga River water in Cameroon. The $\delta^{13} \mathrm{C}$ was enriched during high flows, and depleted during low flows. They related these variations to different vegetation types in the watershed, namely plants with $\mathrm{C} 4$ metabolic pathways in grass-dominated savannah

contributed higher $\delta^{13} \mathrm{C}$ than $\mathrm{C} 3$ vegetation growing adjacent to the river bank. Goñi et al. (1998) proposed a similar process contributing to sedimentary organic matter measured 
for $\delta^{13} \mathrm{C}$ on specific isolates in the Mississippi River delta. Based on lignin analysis and ratios of phenolic compounds, they showed that a small portion of sedimentary organic matter was terrigenous in origin and that its $\delta^{13} \mathrm{C}$ variation was due to a mixture of soil organic matter from C4 and C3 plant material. In contrast, Barth et al. (1998) concluded that $\delta^{13} \mathrm{C}$ variations ( $\sim 6.0$ per mil) of POC in the upper St. Lawrence river was primarily due to photosynthetic production. This was most prevalent in near-shore or embayment areas of the river. The $\delta^{13} \mathrm{C}$ of POC in the main channel varied to a lesser degree, but they concluded that the bulk of the POC was derived from photosynthesis in the Great Lakes. Similar variations in $\delta^{13} \mathrm{C}$ of POC have been noted in the Great Lakes (Hodell and Schelske, 1998).

Other isotopic works have been conducted in ocean settings for source indication (Williams et al., 1992), the Amazon for biogeochemical cylcling (Hedges et al., 1986; Quay et al., 1992). Other relevant work are isotopic studies of soil organic matter to determine natural cycling rates (Trumbore, 1993; Harrison et al., 1993, Torn et al., 1997), turnover of carbon pools using natural $\delta^{13} \mathrm{C}$ variations (Heidmann and Scharpenseel, 1992; Wedin et al., 1995), and processes that control stable isotopic changes during soil aging (Natelhoffer and Fry, 1988).

The isotopic composition of bulk DOC in surface water has been measured in at least one study of a small watershed, where $\delta^{13} \mathrm{C}$ and ${ }^{14} \mathrm{C}$ measurements were made to compare against groundwater and soil water values to understand the relation (Schiff et al., 1990; Schiff et al., 1997). In a more recent example, isotopic abundances of humic substances in soil and water were conducted to elucidate effects of land use change on their turnover (Kalbitz et al., 2000). Isotopic analysis of groundwater DOC has been developed 
specifically as age-dating tools (Wassenaar et al., 1990; Artinger et al., 1996). In these studies humic substances were isolated specifically for measurement.

\section{Missouri River System}

The Missouri River above St. Louis is one of the great rivers of the world in terms of its length (2533 miles, or $4075 \mathrm{~km}$ ) and drainage area $\left(529,400 \mathrm{mi}^{2}\right.$, or 1,370,000 $\left.\mathrm{km}^{2}\right)$, but not in terms of its average discharge, which is only about 78,570 cfs (van der Leeden, 1975; Fig. 2). The river originates at the continental divide in Montana and joins the Mississippi River about 15 miles above St. Louis, Missouri, and en route drains much of the Great Plains of the USA and southernmost Canada. Along its length the character of the river changes markedly, from a fast clearwater stream fed by alpine snowmelt, through 5 major impoundments in the midwestern plains, and ultimately to a large meandering channel in the State of Missouri, where the average gradient is only 0.85 feet per mile. Annual precipitation in the prairie-dominated midwestern plains (avg. 20 in/yr) is much lower than in the woodland-dominated lower river area of Missouri (avg. $\sim 40 \mathrm{in} / \mathrm{yr})$. 


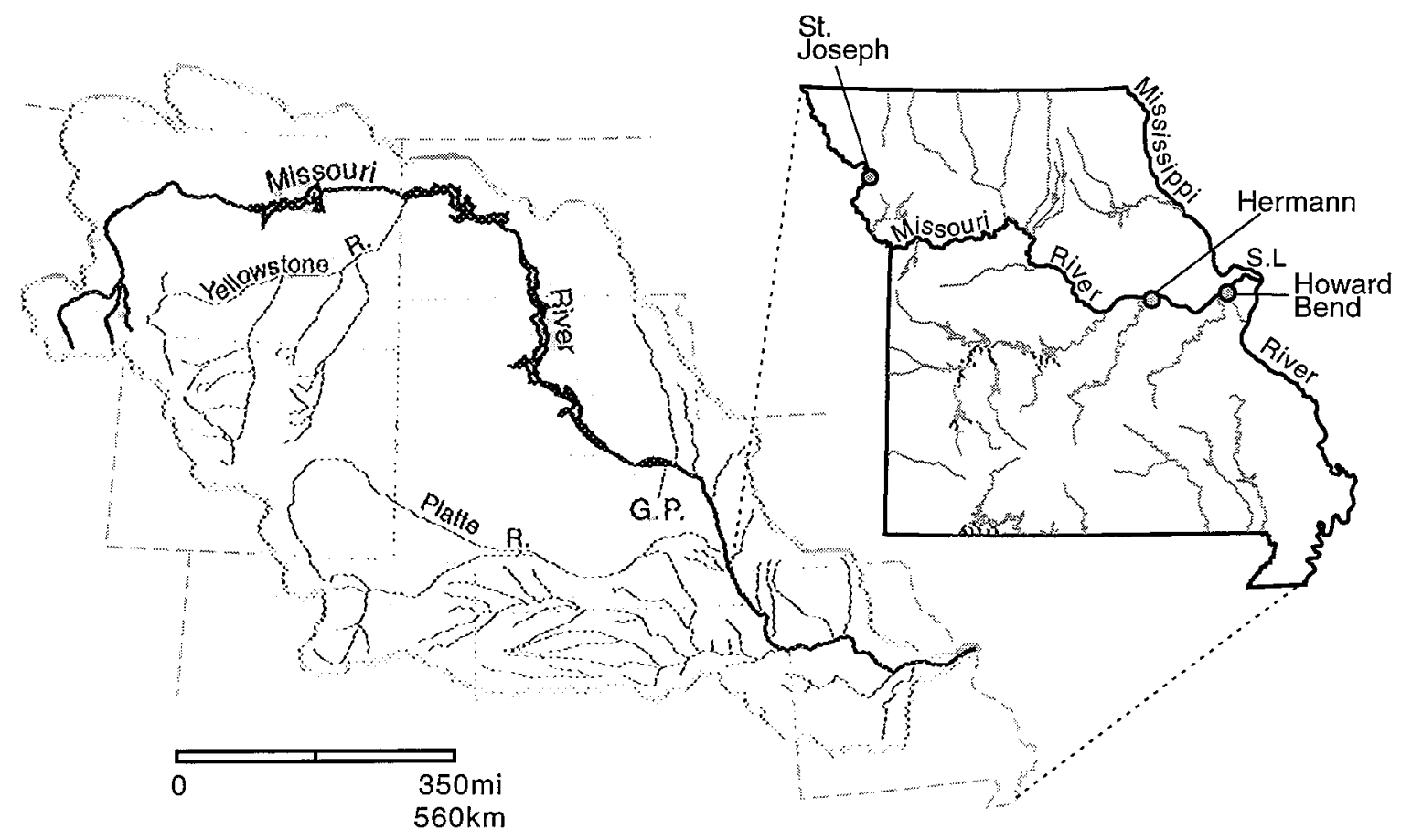

Figure 2. Missouri River Basin and sampling points in Missouri for this study. Note the Missouri River is largely dammed in the upper portion of the watershed, while the lower watershed is mostly navigable waters.

Several aspects of Missouri River water are distinctive. Although the river has a typical Ca-Mg bicarbonate chemistry, an unusual aspect is that the dissolved solid content decreases downstream across the state of Missouri (Homyk and Jeffery, 1967). The river is famous for its high sediment load, yet this load may have been even higher before cultural development of the watershed. Concentrations of agrochemicals are a growing concern for this and many other midwestern rivers (e.g., Thurman et al., 1991).

Streamflow variations of the Missouri River are also unusually large for a river of its size. During the last 40 years, daily mean streamflow at the Hermann, Missouri gauging station has varied from $6210 \mathrm{cfs}$ (Dec. 23, 1963) to 739,000 cfs during the July 31, 1993 flood peak, representing more than a hundredfold variation (Hauck et al, 1997). Flows 
outside these extremes are estimated if the historical period is extended, for example, to include the 1844 flood.

The modern appearance of the Missouri River belies its natural, predevelopment character. Historically the river was braided with an anastomosing channel that included many small islands and bars (e.g., Izenberg, 1996; Patrick, 1998). Wildlife was abundant but the numerous snags, sand bars and caving banks presented severe hazards to navigation, even for small vessels as lucidly described by Lewis and Clark. Catastrophic losses during the steamboat era led to snag removal and other navigational improvements, and by the 1930 's, the river was engineered to a single channel by dredging and by construction of levees, wing dams, and bank stabilization works. Across the state of Missouri, the transformation of the natural river to its nearly invariant channel with a 9 foot minimum depth was effected by an $8 \%$ reduction in total length, a $50 \%$ reduction in the water surface area, a 98\% reduction in island area, and the removal of nearly 20,000 snags (Funk and Robinson, 1974).

\section{Data Sources, Field Sampling and Analytical Techniques}

This study utilized daily water quality analyses generated by the City of St. Louis Public Works, Howard Bend Plant on the Missouri River. They generate daily values for electrical conductivity, $\mathrm{pH}$, temperature, and alkalinity all by standard EPA methods. They also collect daily stage measurements of river height. These stage measurements are converted to discharge by comparing them to discharge records at the US Geological Survey gauging station at Hermann, Missouri, approximately 60 miles upstream. The discharge at Hermann is highly correlative with Howard Bend stage measurements. 
Additional data is collected by the US Geological Survey stream gauging stations through the watershed and available on the web.

Daily to bi-weekly samples for $\delta^{18} \mathrm{O}$ measurements were collected by Howard Bend personnel and Robert Criss at Washington University of St. Louis. All $\delta^{18} \mathrm{O}$ data was generated at Washington University using standard $\mathrm{CO}_{2}$ equilibration techniques followed by isotope ratio mass spectrometry. Isotopic abundances are reported as a ratio to a know standard and converted by the equation

$$
\delta=\left(\frac{R}{R_{\text {std }}}-1\right) 1000
$$

where $R$ is the isotopic ratio of either ${ }^{18} \mathrm{O} /{ }^{16} \mathrm{O}$ and $R$ std is the isotopic ratio of a known standard.

In addition, 10 samples were collected over the course of one year for isotopic analysis of DOC and is humic fractions. Samples were collected in one liter pyrex bottles precombusted at $500^{\circ} \mathrm{C}$ for 3 hours. A few drops of concentrated mercuric-chloride were added in the field to poison any microbes potentially metabolizing the DOC. Samples were stored on ice in the dark. Samples were filtered at $0.45 \mu \mathrm{m}$ filter constructed of either pre-combusted glass fiber, polysulfone, or nylon pre-flushed with 2 liters of MilliQ UV Plus lab water with a DOC concentration $<0.1 \mathrm{mg} / \mathrm{L}$.

DOC measurements were made on a Shimadzu $5000 \mathrm{~A}$ by high temperature combustion to $\mathrm{CO}_{2}$ followed by IR detection and quantification. For isotopic analyses of bulk DOC, 0.5 to 1.0 liter of filtered water was rota-evaporated to $\sim 10 \mathrm{ml}$ and then acidified with ultrapure $6 \mathrm{~N} \mathrm{HCl}$ to volatilize inorganic carbon. The solution was freeze dried, and the powder was homogenized and stored in a glass vial inside a container of 
desiccant. The powder was combusted in vacuum seal vicor tubing with $\mathrm{CuO}$ at $900^{\circ} \mathrm{C}$ for 3 hours. The $\mathrm{CO}_{2}$ was cryogenically purified on a vacuum line, split for $\delta^{13} \mathrm{C}$ determination by isotope ratio mass spectrometry, and the remainder was converted to graphite and analyzed for ${ }^{14} \mathrm{C}$ on an accelerator mass spectrometer at LLNL (Vogel et al., 1987). The $\delta^{13} \mathrm{C}$ is reported in the same format $\delta^{18} \mathrm{O}$. The ${ }^{14} \mathrm{C}$ is reported as a percent of modern carbon (pmc) relative to a 1950 atmospheric $\mathrm{CO}_{2}{ }^{14} \mathrm{C}$ standard (Stuiver and Polach, 1977).

DOC was fractionated into its humic substances using XAD-8 resin, following the methods of Thurman and Malcolm (1981). 1-2 liters were pumped over the XAD-8 at 0.5 $\mathrm{L} / \mathrm{hr}$ at $\mathrm{pH}$ 2.0. The sorbed humic substances were eluted with $0.1 \mathrm{~N} \mathrm{NaOH}$. No attempt was made to extract the small residual retained on the resin. Eluates were acidified to $\mathrm{pH}$ of 1.0 with ultrapure $\mathrm{HCl}$ to separate humic acids from fulvic acids. This took in some cases more than one month because of the low humic acid content. The humic acid was separated by centrifugation and the both humic fractions were freeze-dried, combusted, and prepared by the same method as the bulk DOC.

\section{Results and Discussion from the Missouri River}

Discharge and Electrical Conductivity Relationship

Discharge of the Missouri has a seasonal cycle, with maximum annual flows occurring between March and May. Seasonal changes in river discharge cause a proportional change in the electrical conductivity (EC) from as low as $\sim 200 \mu \mathrm{S}$ to greater than $900 \mu \mathrm{S}$ (Fig. 5). Low EC typically correlates with high discharge, whereas high EC occurs during 
baseflow periods. Also, EC decreases downstream along the entire length of the Missouri River.

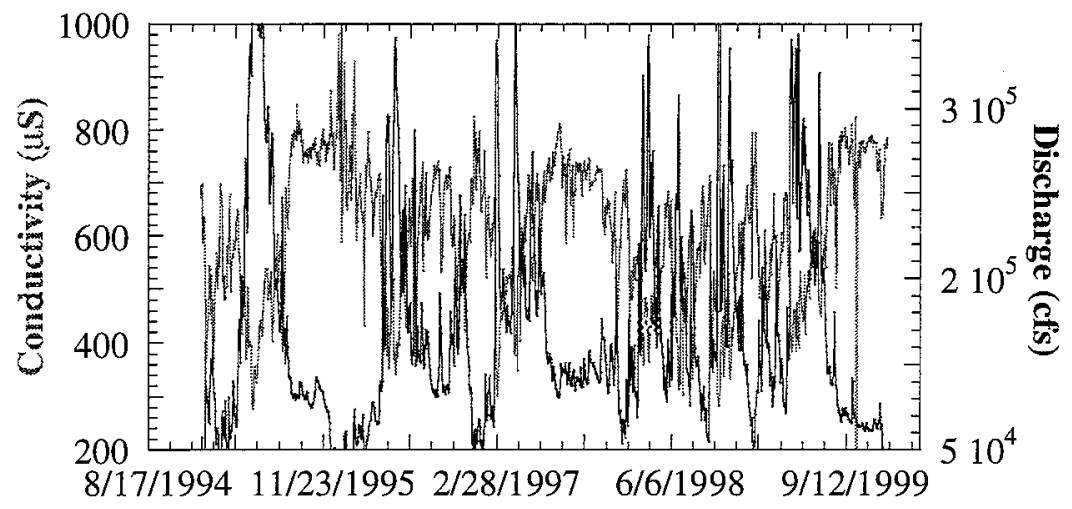

Figure 5. Electrical conductivity decreases when Missouri River discharge increases at Hermann, MO. The large variation in conductivity is unusual for big rivers and suggests that baseflow has a distinct chemical source.

An important element to tracing the source of water quality requires some predictable knowledge of water mass transport in a river system. In particular, a quantitative basis is needed for assessing the source of water in order to establish water quality origin. We can assume that many water quality parameters act conservatively during transport, and result from processes that generate them in their source area. For example, the Missouri River EC varies with river discharge, suggesting that concentration is controlled by source. In order to assess the sources, the geographic areas contributing to EC need to be understood. In the most simplest and ideal cases, the EC would be controlled by one source. This is not necessarily an intuitive hypothesis given the geographic extent and complexity of the Missouri River system. However, increased flow is commonly associated with spring run-off, derived from snow melt and precipitation drainage and ideally represents a non-salt source or dilutant. As a demonstration, a simple test of a single source would be to compare EC with the inverse of river flow. However, the EC and inverse discharge do not form a strong linear relationship $\left(r^{2}=0.42\right)$, indicating more 
that one source contributes to dissolved salt and a single source model for EC is not valid. Therefore, to gain insight into potential source areas the oxygen-18 data could provide good evidence, since it varies with geographic area.

\section{Oxygen-18 in the Missouri River}

$\delta^{18} \mathrm{O}$ values generated for Missouri River water collected at the Howard Bend Plant from 1995-1996 and after March, 1998 (El Nino) show a stronger inverse linear relationship with conductivity (Fig. 6).

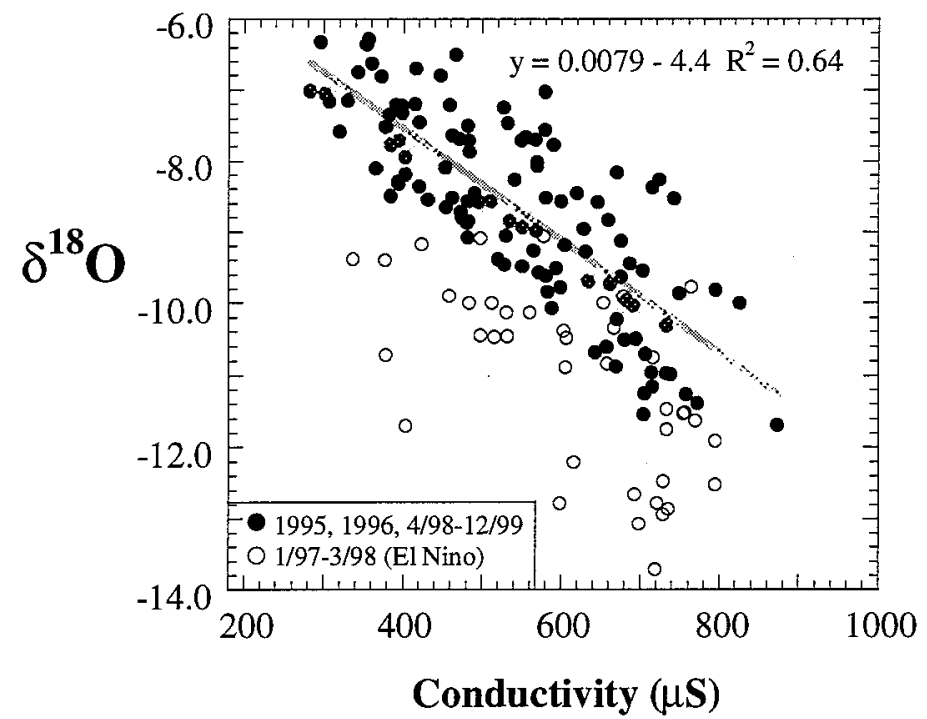

Figure 6. A good inverse correlation exists between conductivity of Missouri River water and its $\delta^{18} \mathrm{O}$ value. Lower $\delta^{18} \mathrm{O}$ values correspond to upper watershed sources, which have higher dissolved salt content. This trend was disrupted during the 1998 El Nino event.

Recall that the $\delta^{18} \mathrm{O}$ value of precipitation and runoff varies geographically in continental environments, where values are more negative for areas of cooler temperature and also with increased distance from the ocean. The upper part of the Missouri River watershed includes cold alpine environments of Montana and Wyoming, whose annual snow packs provide much of the reservoir storage in the upper river. Snow melt water typically has 
low $\delta^{18} \mathrm{O}$ values (-12 to -19 per mil), with average values reported for the upper Missouri between -15.8 and -17.6 per mil, the Yellowstone River at -17.7 per mil, the North Platte River between -15.4 and -16.1 per mil, and the Missouri River at Fort Randall of $13.8 \pm 0.7$ per mil (Coplen and Kendall, 2000). Below the reservoirs, the tributaries to the Missouri River drain lower elevation watersheds whose $\delta^{18} \mathrm{O}$ values will be less negative than that derived from Montana or Wyoming. For example, for the lower Platte River near the town of Louisville, the average $\delta^{18} \mathrm{O}$ value has been reported at $-9.1 \pm 1.5$ per mil (Coplen and Kendall, 2000). In the lower Missouri River, average $\delta^{18} \mathrm{O}$ values range from -6.1 to -6.8 per mil in smaller tributaries (Frederickson and Criss, 1999; Coplen and Kendall, 2000).

The $\delta^{18} \mathrm{O}$ value of the Missouri River sampled at Howard Bend varies during the year from less than -13 per mil to greater than -7 per mil. This is consistent with discharge derived from either the upper watershed, lower watershed, or a combination of both. The exception to this is that during the winter, cold arctic storms produce regional precipitation (typically as snow) with low $\delta^{18} \mathrm{O}$ values (less than -10 per mil) in the lower watershed (see Fredrickson and Criss, 1999). Nevertheless, a simple two end-member approach (i.e. upstream versus downstream) is adequate for interpreting the $\delta^{18} \mathrm{O}$ observations at Howard Bend. Likewise, since the $\delta^{18} \mathrm{O}$ data show a good inverse correlation with EC, a simple two end-member approach also explains the source of dissolved salts in the Missouri River.

From Figure 6 it is logical to suggest that EC may be primarily controlled by two different salt sources. This may be a more plausible case for the simple reason that the Missouri River is characterized by an upstream component that has a semi-arid to 
temperate climate, and a downstream component that is temperate to humid. Mean daily discharge nearly doubles between discharge points at the lower end of each flow component (i.e. St. Josephs, $\mathrm{MO}$ and St. Louis, MO).

\section{Geographic Separation of Discharge and Water Quality}

An alternate test on a two end-member source entails segregating the water quality data in terms of mass discharge. For example, we can separate the discharge measured at Howard Bend into an upstream and downstream component by recognizing

$$
X_{H e r}=\frac{D_{H e r}-D_{S J}}{D_{H e r}}
$$

where $D_{S J}$ is the measured discharge at an upstream point, $D_{H e r}$ is the measured discharge at a downstream point, and $X_{H e r}$ is the fractional amount of discharge contributed between those two points. If a simple two end-member source of water quality is valid, then a comparison between a water quality parameter and the fraction of discharge $(X)$ from either upstream or downstream should result in a linearized relationship.

The fraction of downstream discharge $\left(X_{H e r}\right)$ was calculated from daily mean flows at St. Josephs and Hermann from 1995-1999. The daily mean discharge values measured at Hermann were offset four days in order to appropriately pair them to the St. Josephs data, since discharge has approximately a four day travel between these two locations (Criss et al., 2001). Calculated fractions of downstream flow are plotted against $\mathrm{EC}$ and $\delta^{18} \mathrm{O}$ in Figures $7 \mathrm{a}$ and $7 \mathrm{~b}$. As seen, the correlation between daily EC measurements and the fraction of downstream flow is linear $\left(\mathrm{R}^{2}=0.62\right)$. The relationship between the fraction of flow and $\delta^{18} \mathrm{O}$ is not as well constrained. This is likely due to complicating factors 
such as anomalous $\delta^{18} \mathrm{O}$ storm events (e.g. wintertime) that locally produce large discharge events either upstream or downstream. Nevertheless, the variation in EC appears to be strongly driven by the amount of upstream flow. The linear extrapolation through the data suggest that an end-member EC $\left(X_{H e r}=0\right)$ is $838 \mu \mathrm{S}$, whereas a downstream source $\left(X_{H e r}=1\right)$ is $219 \mu \mathrm{S}$. Monthly average EC and discharge values improve the linear correlation $\left(\mathrm{R}^{2}=0.82\right)$, which can facilitate reliable salt load calculations (Criss et al., 2001). The daily and monthly EC values are far better constrained by separating discharge into geographically controlled flow components rather than simple comparisons with discharge at a single point.

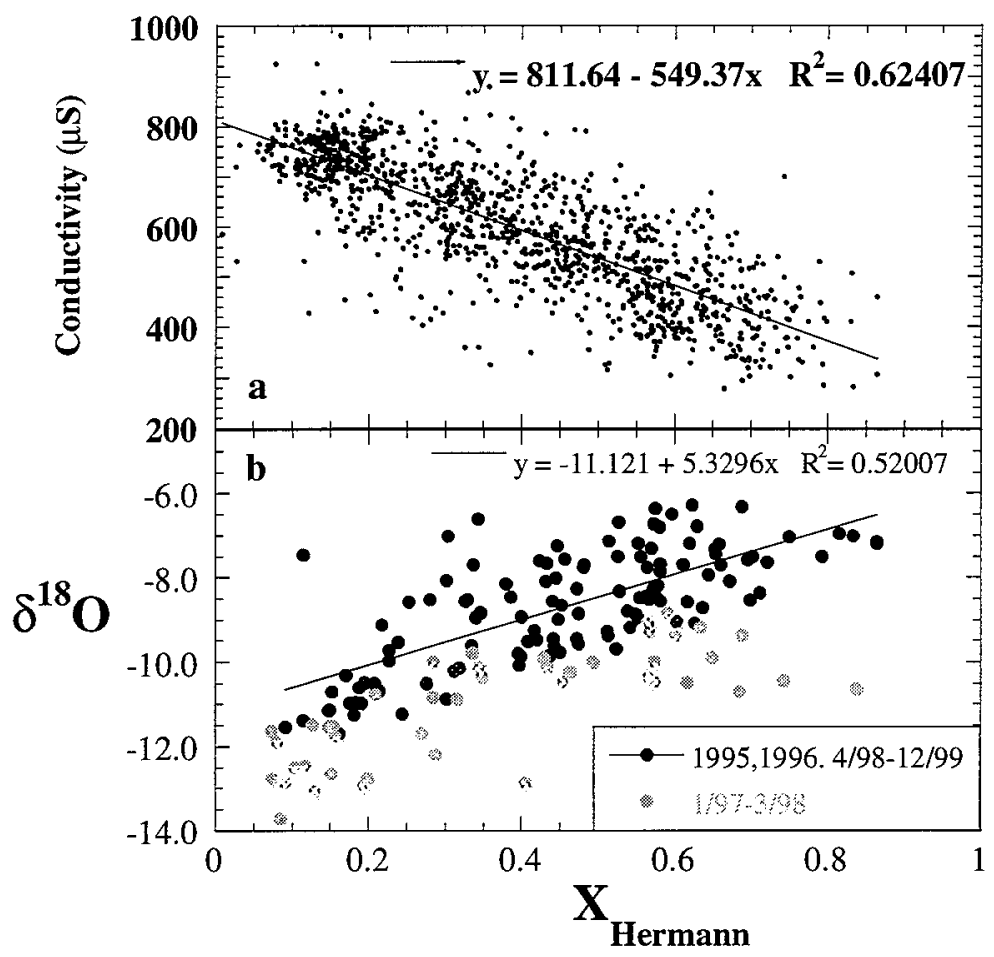

Figure $7 \mathrm{a}$ and $7 \mathrm{~b}$. The fraction of downstream discharge $\mathrm{X}$ correlates linearly with the conductivity and $\delta^{18} \mathrm{O}$ of the Missouri River water, indicating two principle sources of water quality.

Monthly average concentrations of water quality parameters collected at Howard Bend also show linear correlation with the fraction of downstream flow (Figs. 8abc). These include cations of $\mathrm{Ca}, \mathrm{Mg}$, and $\mathrm{Na}(\mathrm{R}=0.70,0.65,0.89$ respectively $)$, anions of $\mathrm{HCO}_{3}$, 
$\mathrm{SO}_{4}$, and $\mathrm{F}(\mathrm{R}=0.67,0.87,0.84$ respectively $)$, and DOC $\left(\mathrm{R}^{2}=0.63\right)$. Other constituents such as $\mathrm{NO}_{3}, \mathrm{Cl}, \mathrm{K}$, turbidity, and microbiology showed poor correlation to the fraction of flow. In these cases, either more than two sources contribute these constituents to discharge measured at Howard Bend, or in-stream processes are significantly changing their concentrations.
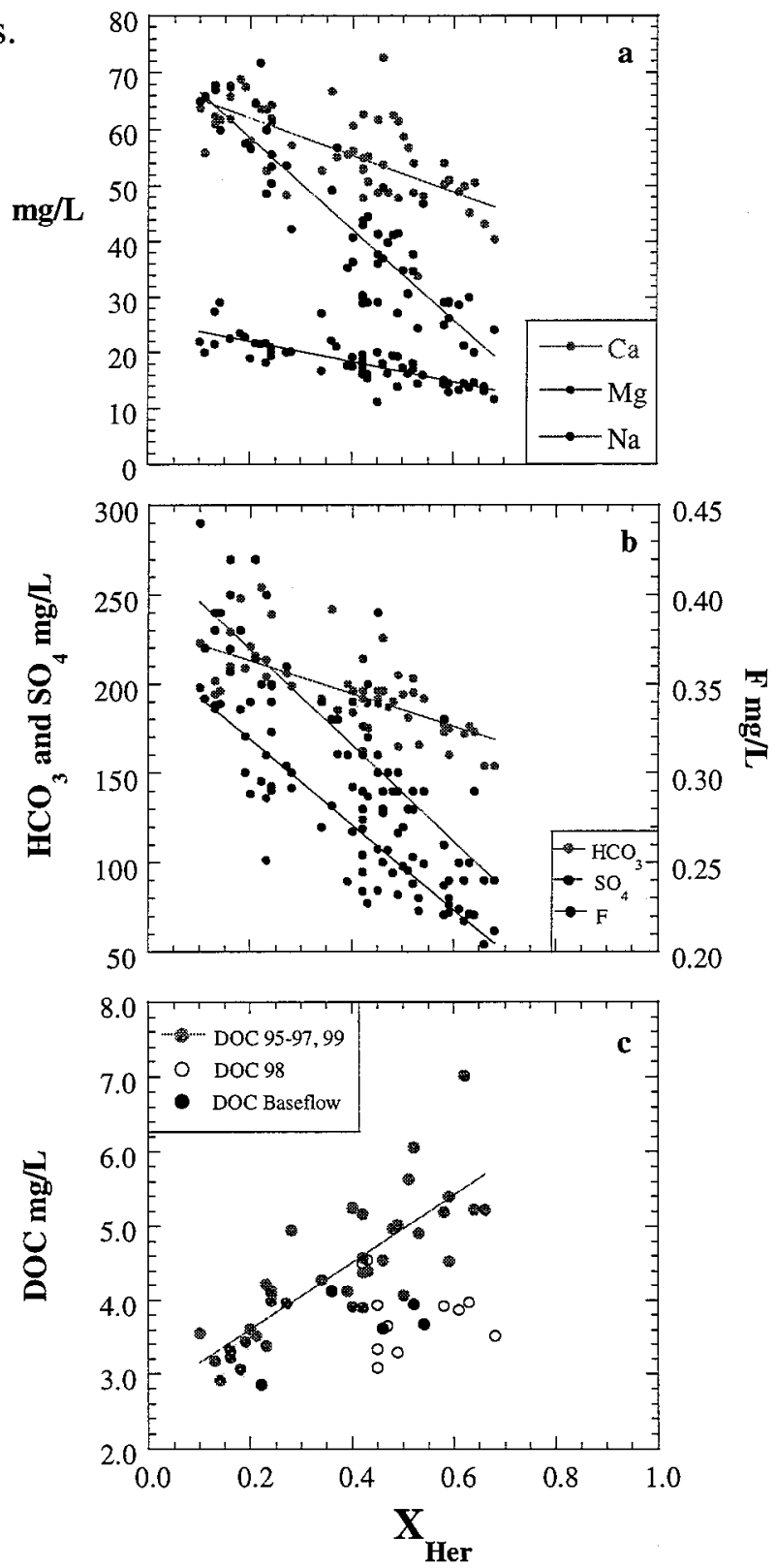

Figure 8abc. The Fraction of downstream runoff correlates with more inorganic water quality constituents that comprise the conductivity measurement. The DOC concentration also correlates with the $X_{H e r}$ parameter, suggesting a simple two source model for its origin. 


\section{Dissolved Organic Carbon}

The correlation between the fraction of discharge and DOC is integral to the ultimate results in this study and some details of this correlation need clarification. For example, DOC concentrations for the El Nino period of 1997-1998 were unusually low and were not included in the linear regression. It is still unclear why the DOC was low during this period, although an unusually steady baseflow period persisted from June, 1997 to March, 1998, and the spring runoff pulse in 1997 was fragmented and not persistent. However, the total discharge over the year, and also from March through July of each year, was similar between El Nino and non-El Nino years. Also separated from the linear regression are DOC values generated in January of each year. This month is always marked by a minimum baseflow period, and DOC values unpredictably vary probably due to groundwater contributions.

Even though monthly average DOC correlates to fraction of discharge, the daily values show a poor correlation. This suggests local effects control the instantaneous DOC concentration, which may include 1) various local geographic sources contributing shortterm DOC loads, 2) algal blooms, 3) rainfall and runoff intensity, and 4) season. Given these as additional variables contributing to DOC on a daily basis, they still represent second-order variables in regards to long-term sources of DOC. In particular, since the DOC monthly averages correlate to the fraction of downstream discharge, regional geography represents the first-order control on DOC source. 


\section{Humic Content of Dissolved Organic Carbon}

Ten samples of Missouri River were collected at Howard Bend over the course of one year for detailed isotopic analysis of DOC. In particular, the ${ }^{14} \mathrm{C}$ and ${ }^{13} \mathrm{C}$ abundance were measured on the DOC and the humic fractions isolated from each sample. The DOC concentration was measured both by LLNL and the City of St. Louis, and analyses agree well.

The DOC concentration varied from $<3 \mathrm{mg} / \mathrm{L}$ to $>5 \mathrm{mg} / \mathrm{L}$ among the ten samples. The lowest concentration was in late summer of 1997 during a long baseflow period. Highest concentration was during spring runoff in 1998. The DOC concentrations of these ten samples show little correlation to daily discharge in the Missouri River. Typically, the DOC concentration is higher on average during the spring to early summer corresponding to seasonal snow melt and rain storms (Fig. 9). Instantaneous DOC concentrations do not form a simple linear correlation with discharge, and during the period for which these ten samples were collected (El Nino), the DOC concentrations were unusually low.

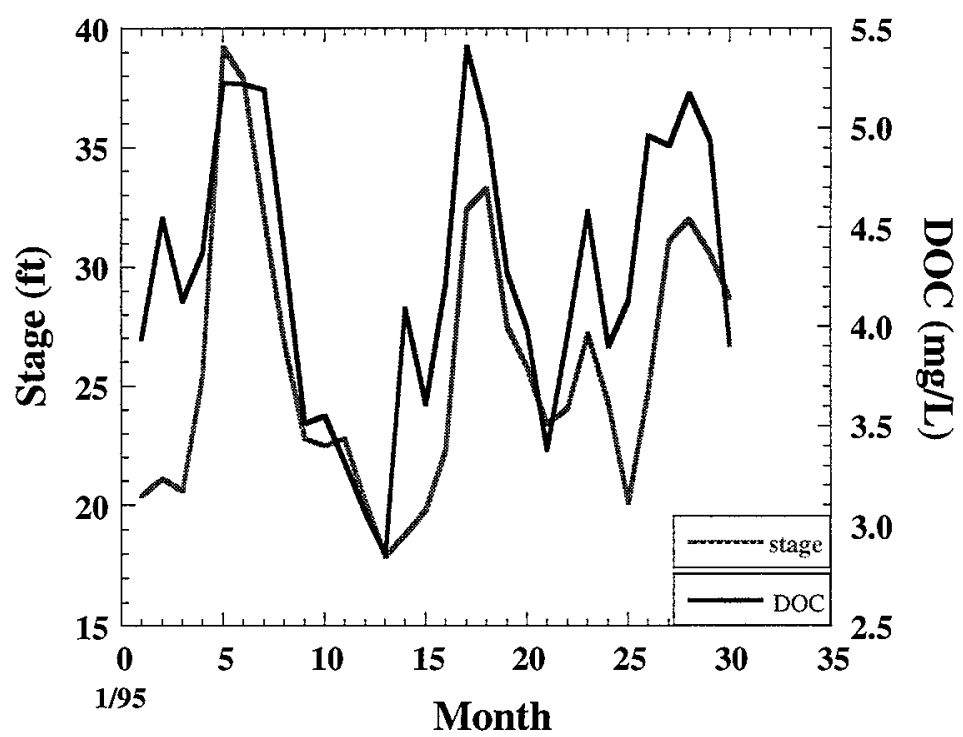

Figure 9. Monthly average DOC values correlate well with monthly stage (and discharge) of the Missouri River at St. Louis. Daily values show a more poor correlation. 
The humic content was determine on 6 of the ten samples collected by using non-ionic resin techniques (XAD-8) already outlined above. The humic content ranged between $43 \%$ and $61 \%$ of the DOC. The lowest were during September, 1997 and February, 1998 during low flow periods. The percent humic content did not correlate with the fraction of downstream discharge. The humic fraction was dominated by fulvic acids (soluble in acid) as shown by low humic acid yields after acidification of XAD-8 eluates. In particular, humic acids typically required two weeks to a month to precipitate from solution, indicating low concentration in eluate solutions. Low concentrations of humic acids are typical for river and stream humic substances (Malcolm, 1985).

\section{$\underline{\text { Radiocarbon of Dissolved Organic Carbon and Humic Fractions }}$}

The ${ }^{14} \mathrm{C}$ content of DOC was measured on all ten samples collected and range from 115 pmc to 94 pmc (Fig. 10). The highest values were in September, 1999 and February, 1998. The lowest ${ }^{14} \mathrm{C}$ content was in the sample collected in January, 1998. The variation in ${ }^{14} \mathrm{C}$ content did not correlate with river discharge, the fraction of downstream discharge, or DOC concentration.

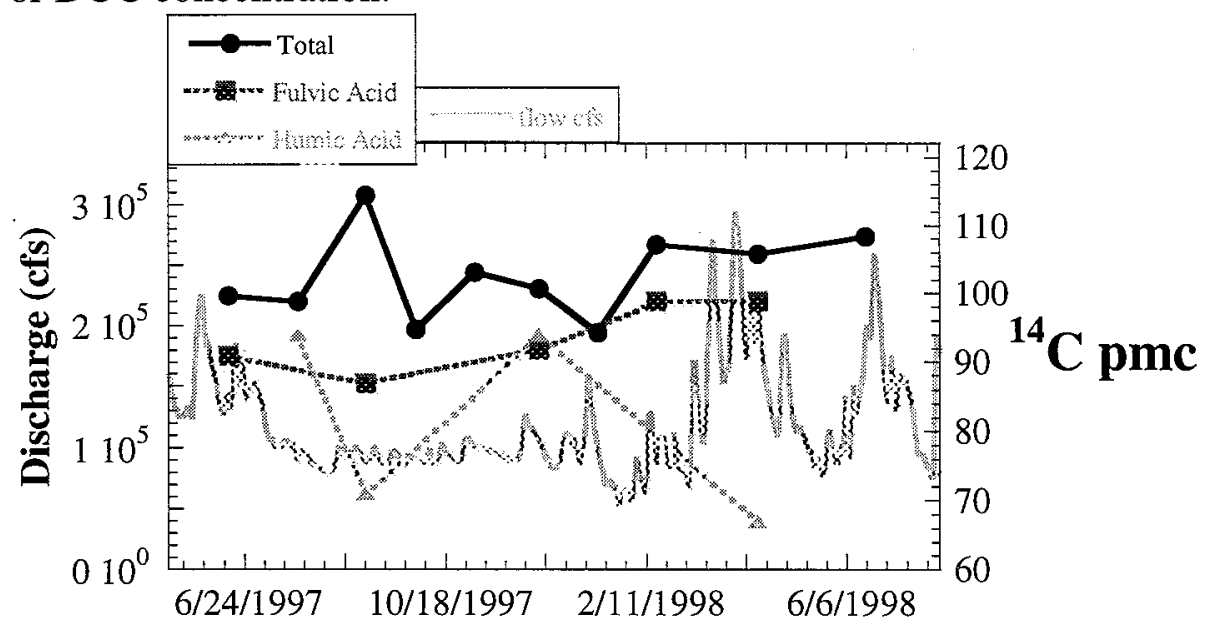

Figure 10 . The ${ }^{14} \mathrm{C}$ abundance in $\mathrm{DOC}$ and humic fractions of DOC show variation during the course of one year that do not correlate to discharge. The humic fractions are distinctly older than the bulk DOC. 
Of particular note, however, is a correlation between the ${ }^{14} \mathrm{C}$ content of DOC and the ratio of humic substances to DOC (Fig. 11). In this case, the ${ }^{14} \mathrm{C}$ content of the DOC decreases with increasing humic content. This indicates that the humic substances have an older mean age than the DOC (Fig. 10). Providing that the data relation varies on a linear scale, the regression suggests that for a given DOC with no humic content (Humic/DOC $=0$ ), the ${ }^{14} \mathrm{C}$ would be $140 \mathrm{pmc}$, whereas if the DOC was $100 \%$ humic (Humic/DOC = 1), then the ${ }^{14} \mathrm{C}$ would be 63 pmc. These postulated end-member ${ }^{14} \mathrm{C}$ values are not inconsistent with environmental levels of fallout radiocarbon, or with mean ages of soil organic matter (e.g. Trumbore, 1993).

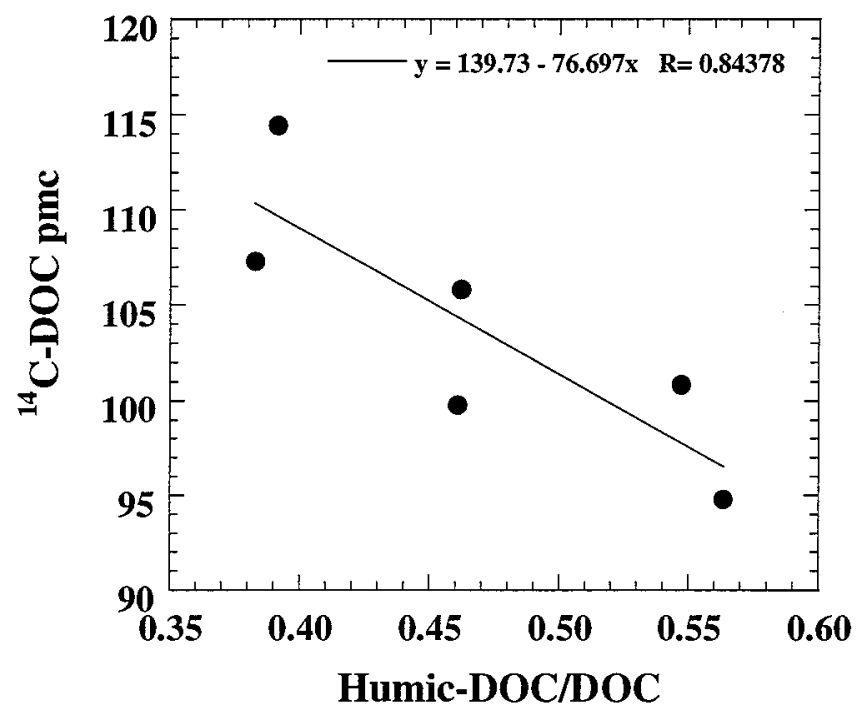

Figure 11 . The ${ }^{14} \mathrm{C}$ abundance of bulk DOC inversely correlates with the fractional amount of humic content, indicating the humics carry the older radiocarbon signature.

The ${ }^{14} \mathrm{C}$ of the 6 fulvic acid fractions isolated varies from $99 \mathrm{pmc}$ to $87 \mathrm{pmc}$, where 4 humic acids measured range from $94 \mathrm{pmc}$ to $67 \mathrm{pmc}$ (Fig. 10). The ${ }^{14} \mathrm{C}$ content of the fulvic acid fraction shows the most remarkable linear correlations with electrical conductivity and the fraction of downstream discharge (Figs. 12ab). These parameters are 
both indicators of water source in the lower Missouri River, and given their excellent correlation with the ${ }^{14} \mathrm{C}$ of fulvic acids, suggests that the latter transports conservatively with the water. The source of fulvic acids are distinguished by their ${ }^{14} \mathrm{C}$ variation. Recall from the previous discussion that the mean electrical conductivity of upper Missouri River discharge was $838 \mu \mathrm{S}$, where lower Missouri River runoff averaged $219 \mu \mathrm{S}$. Using the linear regression in Figure 12a, the ${ }^{14} \mathrm{C}$ of the fulvic acids for these end-members are respectively $83 \mathrm{pmc}$ and $122 \mathrm{pmc}$. This indicates the mean age of the upper Missouri River humics is much older than that of the lower Missouri.
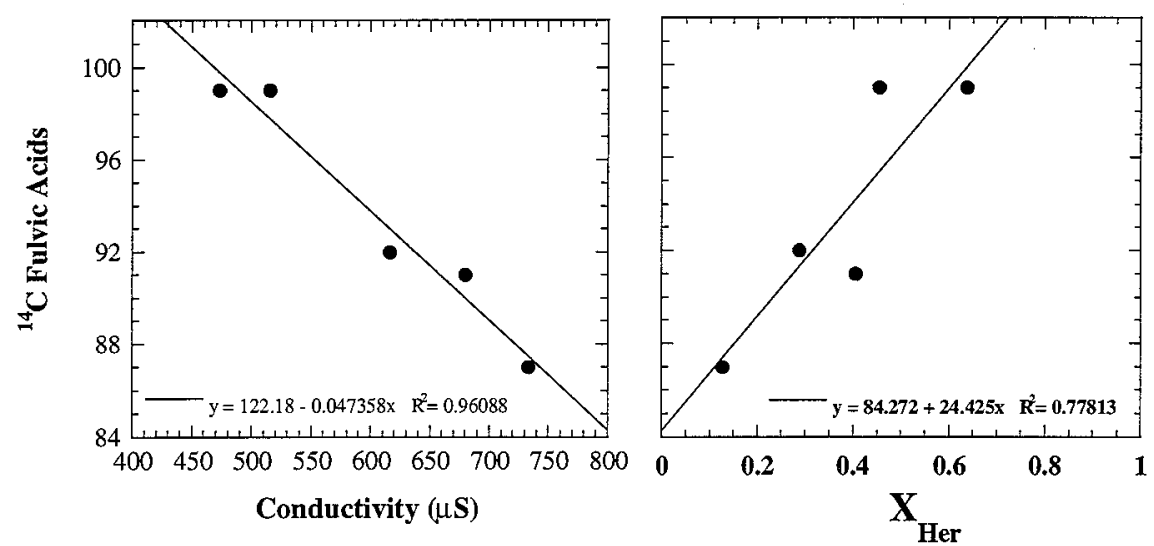

Figure $12 \mathrm{ab}$. The ${ }^{14} \mathrm{C}$ abundance of the fulvic acid fraction of DOC is highly correlated with the conductivity of Missouri River water, and also correlates well with the fraction of downstream discharge.

\section{Geographic Significance of Humic Radiocarbon Content}

Recall that the climate is variable within the Missouri River watershed. The lower Missouri is dominated by southern deciduous woodland vegetation and has a temperate to humid climate with mean annual precipitation averaging 40in/yr. The upper Missouri is mostly mixed prairie grassland of more arid and seasonal climate with mean annual precipitation averaging $\sim 20 \mathrm{in} / \mathrm{yr}$. The headwaters of the Missouri River are the eastern Rocky Mountains of Wyoming and Montana. Vegetation in these areas is mixed alpine 
forest. Annual precipitation is mostly as snow. Most of the snowmelt is impounded annually in five large reservoirs operated by the Army Corps of Engineers on the upper Missouri River. The reservoirs storage likely contributes to evaporation, which increases conductivity of upper river flow.

Climate and vegetative regimes control the quantity and character of dissolved humic substances in the river water (e.g. Thurman, 1985). This is due to the fact that fulvic and humic acids represent the most soluble fraction of soil organic matter, which is the largest pool of humic substances in the aquatic environment (Malcolm, 1985; Aiken and Malcolm, 1987). The different vegetative regimes in the Missouri River watershed are controlled by the variable climate, which results in quite different soil types. For example, woodland forests like the lower Missouri River area have relatively high primary productivity rates. Carbon turnover in the ecosystem can be large and high precipitation rates contribute to annual soil flushing. Deep root systems contribute to appreciable weathering of soils and likely reduce their organic matter retention capacity. Annual leaf litter produced from deciduous trees also contributes to an important young carbon source, which has soluble components having humic character (i.e. hydrolyzable tannins, see Wershaw et al., 1996).

In the grassland dominated region of the Missouri River, the soil organic matter content can be significantly higher. It results mainly from the annual growth of natural grasslands, where spring warming and aerial precipitation contribute to an intense growing season. As temperatures warm and precipitation tapers back, grasses decrease productivity. They eventually die back as temperatures cool. The lower precipitation rates limit the amount of leaching of residual organic matter, and likely reduction in microbial 
degradation. Also, grasses have shallow root structures and do not create a deep and weathered soil profile. This increases the soil retention capacity for organic matter and slows turnover times by reducing its solubility. This also explains the lower average DOC concentration in discharge originating above St. Josephs, MO.

\section{$\underline{\text { Relationship Between Humic Radiocarbon and Climate }}$}

To further test the hypothesis that the ${ }^{14} \mathrm{C}$ of the fulvic acids in Missouri River water were controlled by climate differences in the watershed, several samples of humic substances were collected from different rivers throughout the western hemisphere and measured. These were kindly provided by Jerry Leenheer at the US Geologic Survey, Denver, and represent the hydrophobic acids (fulvic + humic acids) isolated from each river sample. River samples range from equatorial regions of Venezuela to polar sites in Alaska.

Bomb-pulse concentrations were observed for equatorial samples in the Amazon River and the Temi River of Venezula. Bomb-pulse was also observed in humics collected from semi-tropical climates of southeastern Georgia (Suwannee River), and in southern Louisiana (Lake Calcasieu). The San Joaquin River humics of central California also had modern carbon, along with two high latitude samples collected from the Kenai Pennisula (Hidden Lake Creek) and the North Slope of Alaska (Sagav. River). The Missouri River at St. Louis, MO was variable as already shown, ranging from 87 to $99 \mathrm{pmc}$, depending on the timing of the sample. The humics in Clear Creek, a small stream draining the eastern Rockies in central Colorado, was 85 pmc. Lastly, two samples were collected 
from eutrophic lakes of central Nebraska (Island Lake) and western Nevada (Big Soda Lake). Their ${ }^{14} \mathrm{C}$ was 87 and 77 pmc, respectively.

Mean radiocarbon ages of dissolved humic substances in these surface waters throughout the western hemisphere form a positive correlation with local mean annual precipitation (Fig. 13). Mean annual precipitation is a simple first-order measure (exponential curve fit) of net primary productivity in terrestrial ecosystems (Schlesinger, 1994). Bomb-pulse ages are consistently observed for dissolved humic substances in humid to tropical climates, whereas temperate to semi-arid climates mean ages can be up to 1500 years old. The established similarity between riverine dissolved humic substances and degradation products of terrestrial vegetation in soil and plant litter (e.g. Wershaw et al., 1996), suggest that the age-climate correlation is linked to the rate of local primary productivity. However, the range in observed ages indicates a significant retardation before solubilization of dissolved humic substances into rivers and streams, which is likely controlled by the extent of weathering and carbon sequestration capacity of soil (e.g. Torn et al., 1997). 


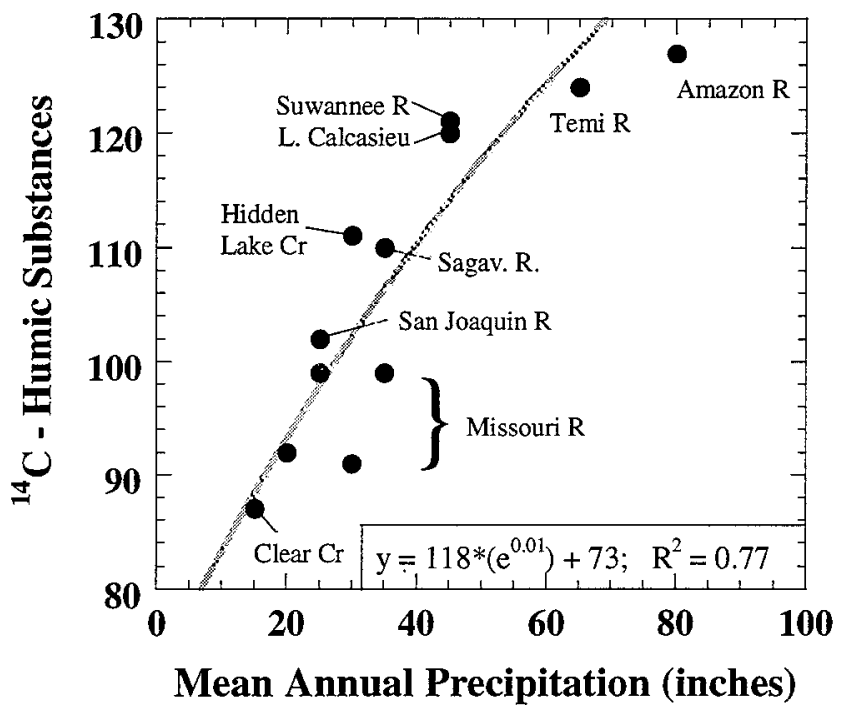

Figure 13. The ${ }^{14} \mathrm{C}$ abundance of the hydrophobic fraction of DOC in several rivers correlates well with the mean annual regional precipitation from each sample location. The abundance related to relative solubility rates of soil carbon entering the rivers.

The correlation indicates that the mean age of the humic fraction of DOC in rivers increases with decreasing net primary productivity. Since the hydrophobic acid fraction of DOC is predominantly soil derived, the correlation indicates that soil carbon storage rates likely dictate the humic and ${ }^{14} \mathrm{C}$ content of the stream DOC. In detail, in equatorial tropical regions the ${ }^{14} \mathrm{C}$ content is bomb-pulse as shown by Hedges et al. (1986), with a mean age $\leq 40$ years, and DOC content (and humic content) is high. In temperate to semiarid regions, the ${ }^{14} \mathrm{C}$ content of the humic fraction has little bomb pulse. Calculated mean ages are as old as 1500 years. Also the humic content and the DOC concentration are much lower than in tropical rivers. In general, the ${ }^{14} \mathrm{C}$ content correlates with net primary productivity of the regional ecosystem as suggested by the mean annual precipitation. However, the range in mean ages suggested by the ${ }^{14} \mathrm{C}$ content (factor of 40 ) are far greater than the range in net primary productivities measured in these environments as well as the mean annual precipitation. Furthermore, it is also known that the content of soil organic matter is quite variable among these environments. In tropical regions, the 
soil organic matter is appreciably lower in temperate regions. Factors such as highly weathered soils, intense microbial actions, frequent rain, and high productivity contributes to the flushing or re-incorporation of DOC into the ecosystem. As already illustrated for the Missouri River, temperate to semi-arid regions have less weathered soil profiles, lower productivities, and less frequent soil-flushing. This contributes to higher soil organic content and longer storage or turnover times into the aquatic environment. This is particularly prevalent in grassland regions. Soil weathering may be the most significant control on carbon storage content in addition to net primary productivity. Less weathered soil is more abundant in divalent cations, which have sequestering power for humic substances. In humid to tropical region, soils are depleted in divalent cations, which contributes to rapid flushing of soil organic matter, lower storage times, and high humic substance content with large nominal size (Aiken and Malcolm, 1987).

\section{Carbon-13 Content of Dissolved Organic Carbon and Humic Fractions}

The $\delta^{13} \mathrm{C}$ value was analyzed on the same samples as the ${ }^{14} \mathrm{C}$. The $\delta^{13} \mathrm{C}$ value of bulk DOC changed approximately 2.5 per mil over the course of one year (Fig. 14). The lowest values were during the wintertime at near baseflow conditions, whereas high values were associated with warmer periods and higher flow. Note that the $\delta^{13} \mathrm{C}$ of the DOC somewhat parallels the annual temperature cycle in the Missouri River, where lower temperatures correlate with more negative values (Fig. 15). The $\delta^{13} \mathrm{C}$ of the DOC does not correlate with the fraction of downstream flow or the humic fraction of the DOC as seen for the ${ }^{14} \mathrm{C}$. This suggests that the $\delta^{13} \mathrm{C}$ is controlled by a process independent of that controlling the ${ }^{14} \mathrm{C}$. 


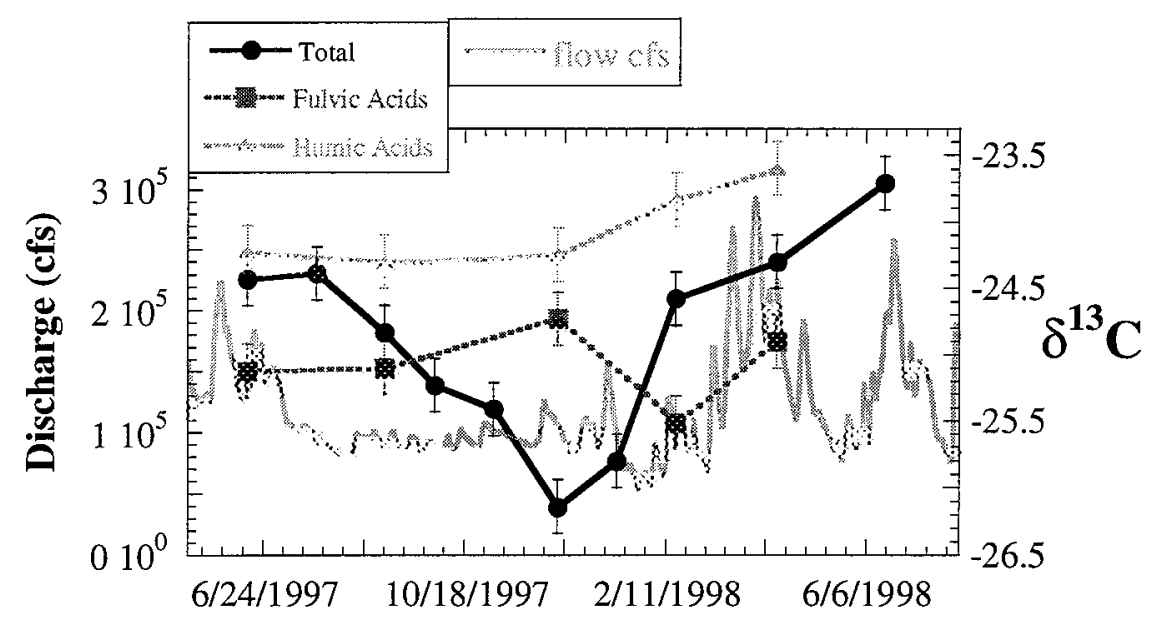

Figure 14. The $\delta^{13} \mathrm{C}$ value of bulk DOC varies over 2 per mil during the course of one year, similar to POC observed by previous workers (Bird et al., 1998 and Barth et al., 1998). The humic fractions show only minor $\delta^{13} \mathrm{C}$ variations suggesting that the bulk $\delta^{13} \mathrm{C}$ variations are not linked to vegetation type, but rather algal production.

The $\delta^{13} \mathrm{C}$ values of the fulvic acid are consistent with previous observation (Thurman, 1985). The fulvic acid fraction does not vary to any significance among the samples measured. This suggest that these soluble humic fractions, likely originating from litter or soils in different parts of the watershed, are not controlled plant sources with $\mathrm{C} 3$ and C4 metabolic pathways, as suggested by Bird et al. (1992). The $\delta^{13} \mathrm{C}$ of the humic acid fraction (typically $\leq 10 \%$ of hydrophobic fraction) is much higher and also shows little variation among the samples measured. The humic acid values are similar to high $\delta^{13} \mathrm{C}$ values measured in decomposed forest soil organic matter (Nadelhoffer and Fry, 1988). The $\delta^{13} \mathrm{C}$ and their low concentration in the water are consistent with humic acids being closely associated with soil organic matter having low solubility (e.g. Stevenson, 1985).

The low $\delta^{13} \mathrm{C}$ variation in the humic fraction of the DOC indicates that most of the seasonal variability of $\delta^{13} \mathrm{C}$ is in the non-humic portion. This and the close relation of the 
$\delta^{13} \mathrm{C}$ variation to water temperature suggest that this non-humic portion comprises variable amounts of soluble detritus originating from algal material.

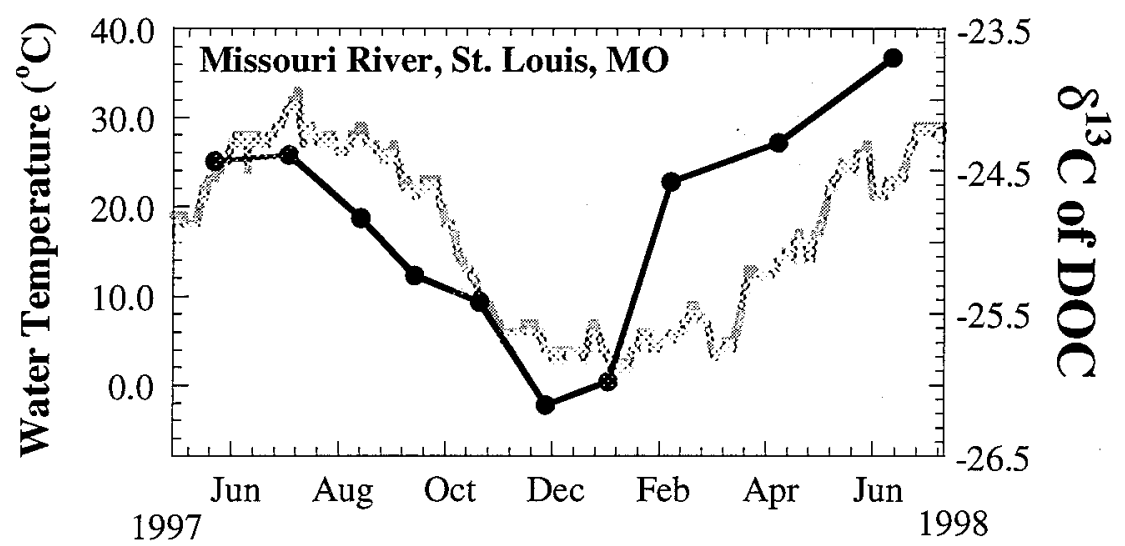

Figure 15 . The $\delta^{13} \mathrm{C}$ of bulk DOC in the Missouri River varies closely with water temperature, suggesting a relationship with autochthonous sources of DOC.

To determine if the amount of DOC originating from algal material is plausible, a mass balance equation is constructed to calculate the ratio of algal DOC to total DOC. It follows that this ratio can be defined by

$$
\frac{D O C_{\text {alg }}}{D O C_{\text {tot }}}=\frac{\frac{\delta^{13} C_{\text {non - alg }}}{D O C_{\text {tot }}}+\frac{D O C_{h m}}{D O C_{t o t}} \delta^{13} C_{h m}-\delta^{13} C_{t o t}}{\delta^{13} C_{\text {alg }}-\delta^{13} C_{\text {non - alg }}}
$$

where subscripts alg, non-alg, tot, and $h m$ refer to, respectively, algal component of DOC, non-algal part of the non-humic portion of DOC (e.g. low moelcular weight acids), total DOC, and the humic substance portion of DOC. If we assume that the $\delta^{13} \mathrm{C}_{\mathrm{alg}}$ is -23 per mil (Thurman, 1985), and the $\delta^{13} \mathrm{C}_{\text {non-alg }}$ is -28 per mil, then $\mathrm{DOC}_{\text {alg }} / \mathrm{DOC}_{\text {tot }}$ ratio can be calculated. Results are plotted against the fraction of humic content in Figure 16. The 
highest algal DOC ratio is for a sample collected in late summer at near baseflow conditions. This sample was collected when upstream discharge comprised $88 \%$ of the flow. The algal DOC of essentially zero is baseflow in mid-winter, when algal production is anticipated to be minimal. The remaining samples represent late winter to early summer runoff. The linear inverse correlation has a y-intercept of nearly 0.5 , suggesting for an end-member water that nearly half its DOC is algal in origin when humics are absent. This end-member may be realistic for reservoir water in the upper watershed during the summertime, but the Missouri River channel itself does not have the requisite surface area to supply this fixation capacity.

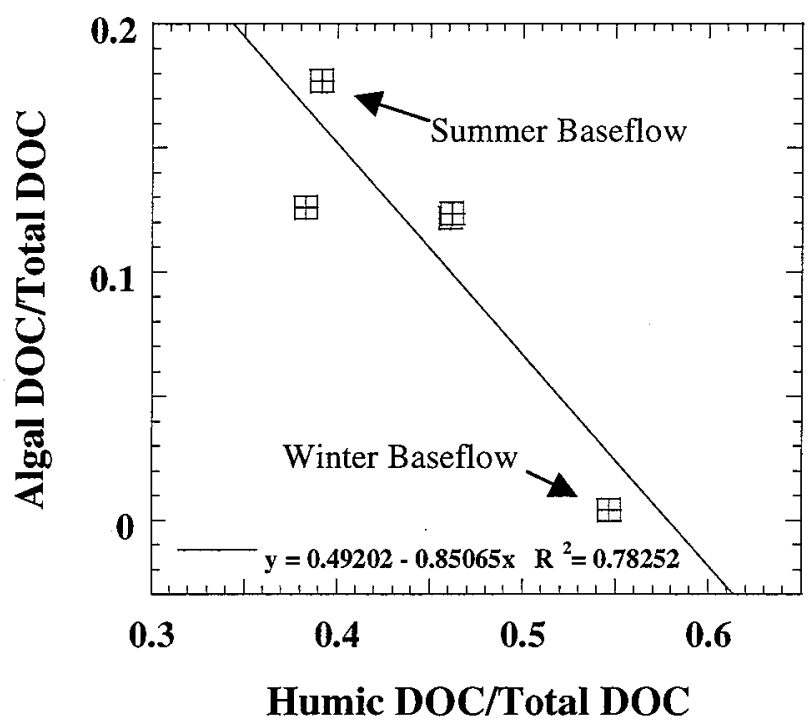

Figure 16. Algal DOC was calculated by mass balance using the DOC concentrations, humic fraction and the $\delta^{13} \mathrm{C}$ values. The highest and lowest algal content correlate to summer baseflow and winter baseflow, respectively.

\section{Summary}

The oxygen-18 abundance of Missouri River water decreases upstream, correlating to the well known continental effect in precipitation. This geographic dependence of oxygen-18 can be used to constrain the geographic source of runoff for large river 
systems. In the Missouri, a strong correlation with dissolved salt content delineated an upstream and downstream source of water controlling water quality at St. Louis, Missouri. The upstream-downstream designation essentially correlates to the climatic shift from dry prairie to moist woodland going downstream on the Missouri.

DOC concentration also correlates with geography, with the carbon-14 content of the humic fraction showing the strongest correlation. Vegetation and soil weathering are highly sensitive to climate, and this is directly reflected in the mean ages calculated from the humic carbon-14 values, where upstream prairie retains soil organic matter longer and downstream woodland yields it rather quickly. As determined from carbon-13 measurements, the upstream reservoirs likely generate a quarter to potentially half the DOC during summer baseflow periods due to algal production.

\section{Acknowledgements}

Bob Criss, Jerry Leenheer, and Jim Kopp are gratefully acknowledged for their assistance in data, samples, and knowledge that help execute this work. This work was performed under the auspices of the U.S. Department of Energy by the University of California, Lawrence Livermore National Laboratory under contract No. W-7405-Eng-48.

\section{References}

Aiken, G.R. and Malcolm, R.L., 1987, Molecular weight of aquatic fulvic acids by vapor pressure osmometry. Geochim. Cosmochim. Acta, 51, 2177-2184.

Aiken, G.R., Mcknight, D.M., Thorn, K.A., Thurman, E.M., 1992, Isolation of hydrophilic organic acids from water using nonionic macroporous resins. Org. Geochem., 18, 567-573.

Amy, G.L., Tompson, J.M., Tan, L., and others, 1990, Evaluation of THM precursor contributions from agricultural drains. Jour. AWWA, Jan, 57-64

Artinger, R., Buckau, G., Kim, J.I., and others, 1996, Influence of sedimentary organic 
matter on dissolved fulvic acids in groundwater. In Isotope in Water Resources Management, International Atomic Energy Agency, Vienna, 1995, pp. 57-72.

Barnes, C.J. and Allison, G.B., 1988, Tracing of water movement in the unsaturated zone using stable isotopes of hydrogen and oxygen. J. Hydrol., 100, 143-176.

Barth, J.A.C., Veizer, J., Mayer, B., 1998, Origin of particulate organic carbon in the upper St. Lawrence: isotopic constraints. Earth and Planetary Science Letters, 162, 111-121.

Bird, M.I., Giresse, P., Ngos, S., 1998, A seasonal cycle in the carbon-isotope composition of organic carbon in the Sanaga River, Cameroon. Limnol. Oceanogr., 43, 143-146

Brinson, M.M., 1976, Organic matter losses from four watersheds in the humid tropics. Limnol. Oceanogr., 21, 572-582.

Coplen, T.B. and Kendall, C., 2000, Stable hydrogen and oxygen isotope ratios for selected sites of the US Geologic Survey's NASQAN benchmark surface water networks. US Geologic Survey Open File Rep. 00-160, 424pp.

Craig H., 1961, Isotopic variations in meteoric waters. Science 133, 1702-1703.

Craig H., Gordon L.I., Horibe Y., 1963, Isotopic exchange effects in the evaporation of water. J. Geophys. Res. 68, 5079-5087.

Craig H. and Gordon L.I., 1965, Deuterium and oxygen-18 variations in the ocean and the marine atmosphere, in Third Spoleto Nuclear Geology Conference on Paleotemperatures and Isotopic Oceanography, Proceedings of the Third Spoleto Conference, Spoleto, Italy, July, 1965, edited by E. Tongiorgi, E., 378 pp.

Criss, R.E., Davisson, M.L., and Kopp, J.W., 2001, Nonpoint sources in the lower Missouri River. Jour. AWWA, 93, 112-122.

Dansgaard W., 1964, Stable isotopes in precipitation. Tellus XVI 4, 436-468.

Ding, W.H., Fujita, Y., Aeschimann, R.; Reinhard, M., 1996, Identification of organic residues in tertiary effluents by GC/EI-MS, GC/CI-MS and GC/TSQ Fresenius Journal Of Analytical Chemistry, 1996 Jan, V354 N1:48-55.

Epstein S., Mayeda T., 1953, Variation of ${ }^{18} \mathrm{O}$ content of waters from natural sources. Geochimica et Cosmochimica Acta, 4, pp. 213-224.

Fiebig, D.M., Lock, M.A., Neal, C., 1990, Soil water in the riparian zone as a source of carbon for headwater stream. J. Hydrol. 116, 217-237.

Frederickson, G.C. and Criss, R.E., 1999, Isotope hydrology and time constants of the unimpounded Meramec River basin, Missouri. Chem. Geol., 157, 303-317.

Friedman, I. Redfield, A.C., Schoen, B. Harris, J., 1964, The variation of the deuterium content of natural waters in the hydrologic cycle. Rev. Geophys., 2, 177-224.

Friedman, I. and Smith, G.I., 1972, Deuterium content of snow as an index to winter climate in the Sierra Nevada Area. Science, 176, 790-793.

Funk, J.L. and Robinson, J.W., 1974, Changes in the channel of the lower Missouri River and effects on fish and wildlife. Missouri Department of Conservation, Aquatic Series No. 11, Jefferson City, Missouri.

Goñi, M.A., Ruttenberg, K.C., Eglinton, T.I., 1998, A reassessment of the sources and importance of land-derived organic matter in the surface sediments from the Gulf of Mexico. Geochim. Cosmochim. Acta, 62, 3055-3075.

Goolsby, D.A., Battaglin, W.A., Aulenbach, B.T., Hoopper, R.P., 2000, Nitrogen fluxes and sources in the Mississippi River basin. Science Total Environ., 248, 75-86. 
Harrision, K.G., Broecker, W.S., Bonani, G., 1993, The effect of changing land use on soil carbon. Science, 262, 725-726.

Hauck, H.S.; Huber, L.G.; \& Nagel, C.D., 1997, Water resources data, Missouri, Water Year 1997. U.S. Geological Survey Water-Data Report MO-97-1.

Hayes, M.H.B. and Swift, R.S., 1978, The chemistry of soil organic colloids. In Greenland, D.J. and Hayes, M.H.B. (eds) The Chemistry of Soil Constituents. John Wiley and Sons: New York, pp. 179-320.

Hedges, J.I., Ertel, J.R., Quay, P.D., et al., 1986, Organic carbon-14 in the Amazon River system. Science, 231, 1129-1131.

Heidmann, P.B., and , H.W., 1992, Studies of soil organic matter dynamics using natural carbon isotopes. Science Total Environ., 117/118, 305-312.

Hodell, D.A. and Schelske, C.L., 1998, Production, sedimentation, and isotopic composition of organic matter in Lake Ontario. Limnol. Oceanogr., 43, 200-214.

Homyk, A. and Jeffery, H.G., 1967, Surface water, in Mineral and Water Resources of Missouri, Missouri Geological Survey, $2^{\text {nd }}$ ser., 43, 258.

Izenberg, N.R., 1996, Assessment of damage from the 1993 floods on the Missouri River floodplain using LANDSAT, SPOT, SIR-C, TOPSAR, and field data. Unpub. Ph.D. dissertation, Washington University.

Kalbitz, K., Geyer, S., Gehre, M., 2000, Land use impacts on the isotopic signature $\left({ }^{13} \mathrm{C}\right.$, ${ }^{14} \mathrm{C},{ }^{15} \mathrm{~N}$ ) of water-soluble fulvic acids in a German fen area. Soil Sci., 165, 728-736.

Lambs, L., 2000, Correlation of conductivity and stable isotope ${ }^{18} \mathrm{O}$ for the assessment of water origin in river system. Chem. Geol., 164, 161-170.

Larson, R. A., and Weber, E. J., 1994, Reactions with Disinfectants, Chapter 4 in Reaction Mechanisms in Environmental Organic Chemistry, Lewis Publishers, Ann Arbor, MI. pp. 275-341.

Lawrence, J.R., Gedzelman, S.D., White, J.W.C., et al., 1981, Storm trajectories in eastern US D/H isotopic composition of precipitation. Nature, 296, 638-640.

Leenheer, J.A.; Croue, J.-P.; Benjamin, M.; Korshin, G.V.; Hwang, C.J.; Bruchet, A.; Aiken, G.R, 2000 Comprehensive isolation of natural organic matter from water for spectral characterizations and reactivity testing. In Barrett, S., Ed. Natural Organic Matter and Disinfection By-Products. ACS Symposium Series _, Wash. D.C., (in press).

Lytle, C.R. and Perdue, E.M., 1981, Free, proteinaceous, and humic-bound amino acids in river water containing high concentrations of aquatic humus. Environ. Sci. Technol., 15, 224-228.

Malcolm, R.L., 1985, Geochemistry of stream fulvic and humic substances. In (Aiken, G.R., McKnight, D.M., Wershaw, R.L., eds) Humic Substances in Soil, Sediment, and Water. John Wiley and Sons New York, pp. 181-210.

Mann, C.J. and Wetzel, R.G., 1995, Dissolved organic carbon and its utilization in a riverine wetland ecosystem. Biogeochemistry, 31, 99-120.

McDowell, W.H. and Wood, T., 1984, Podzolization: Soil processes control dissolved organic carbon concentrations in stream water. Soil Sci., 137, 23-32.

Mulholland, P.J. and Kuenzler, E.J., 1979, Organic carbon export from upland and forested wetland watersheds. Limnol. Oceanogr., 24, 960-966. 
Munster, U. and Chrost, R.J., 1990, Origin, composition, and microbial utilization of dissolved organic matter. In Overback, J. and Chrost, R.J. eds. Aquatic Microbial Ecology, Springer-Verlag: New York, 8-46.

National Research Council, 1999, New Strategies for America's Watersheds. National Acadamy Press: Washington, D.C., 328pp.

Nelson, P.N., Baldock, J.A., Oades, J.M., 1993, Concentration and composition of dissolved organic carbon in streams in realtion to the catchment soil properties. Biogeochem., 19, 27-50.

Nadelhoffer, K.J. and Fry, B., 1988, Controls on natural nitrogen-15 and carbon -13 abundances in forest soil organic matter. Soil Sci. Soc. Am. J., 52, 1633-1640.

Parks, S.J. and Baker, L.A., 1997, Sources and transport of organic carbon in an Arizona River-Reservoir system. Wat. Res., 31, 1751-1759.

Patrick, R., 1998, Rivers of the United States. IV. The Mississippi River and its Tributaies North of Saint Louis. John Wiley \& Sons, New York .

Payne, B.R., Quijano, L., Lattore, D.C., 1979, Environmental isotopes in the study of the origins of salinity of groundwater in the Mexicali Valley. J. Hydrol., 41, 201-215.

Pionke, H.B., Gburek, W.J., Folmar, G.J., 1993, Quantifying stormflow components in a Pennsylvania water shed when ${ }^{18} \mathrm{O}$ input and storm conditions vary. J. Hydrol., 148 , 169-187.

Quay, P.D., Wilbur, D.O., Richey, J.E., et al., 1992, Carbon cycling in the Amazon River: Implications from the ${ }^{13} \mathrm{C}$ compositions of particles and solutes. Limnol. Oceanogr., 37, 857-871.

Ramesh, R. and Sarin, M.M., 1992, Stable isotope study of the Ganga (Ganges) river system. J. Hydol., 139, 49-62.

Rook, J.J., 1977, Chlorination reactions of fulvic acids in natural waters. Environmental Science and Technology, 11, 478-482.

Schiff, S.L., Aravena, R., Trumbore, S.E., Dillon, P.J., 1990, Dissolved organic carbon cycling in forested watersheds: a carbon isotope approach. Water Resour. Res., 26, 2949-2957.

Schiff, SL; Aravena, R; Trumbore, SE; Hinton, MJ; and others., 1997, Export of DOC from forested catchments on the Precambrian Shield of Central Ontario: Clues from C13 and C-14. Biogeochemistry, 36, 43-65.

Schlesinger, W.H., 1997, Biogeochemistry: An Analysis of Global Change. Academic Press: San Diego, 588p.

Sheppard, S.M.F., 1986, Characterization and isotopic variations in natural waters, in Stable Isotopes In High Temperature Geological Processes. Reviews in Mineralogy Vol. 16, edited by J.W. Valley, H.P. Taylor, J.R. O'Neil, 165-184.

Simpson, H.J. and Herzeg, A.L., 1991, Stable isotopes as an indicator of evaporation in the River Murray, Australia. Water Resour. Res., 27, 1925-1935.

Singer, P. C., Ed., 1999, Formation and Control of Disinfection By-Products in Drinking Water, American Water Works Association, Denver, CO

Sklash, M.G. and Farvolder, R.N. 1979, The role of groundwater in storm runoff. $J$. Hydrol., 43, 45-65.

Stevenson, F.J., 1985, Geochemistry of soil humic substances. In (Aiken, G.R., McKnight, D.M., Wershaw, R.L., eds) Humic Substances in Soil, Sediment, and Water. John Wiley and Sons New York, pp. 13-52. 
Stewart, M.K., 1975, Stable isotope fractionation due to evaporation and isotopic exchange of falling waterdrops: Applications to atmospheric processes and evaporation of lakes. J. Geophys. Res., 80, 1133-1146.

Stuiver, M. and Polach, H., 1977, Reporting of ${ }^{14}$ C data. Radiocarbon, 19, 355-363

Sweet, M.S. and Perdue, E.M., 1982, Concentration and speciation of dissolved sugars in river water. Environ. Sci. Technol., 16, 692-698.

Taylor, H.P., Jr., 1974, The application of oxygen and hydrogen isotope studies to problems of hydrothermal alteration and ore deposition. Econ. Geol., 69, 843-883.

Thurman, E.M., and Malcolm, R.L., 1981, Preparative isolation of aquatic humic substances. Environ. Sci. Technol., 15, 463-466.

Thurman, E.M., 1985, Organic Geochemistry of Natural Waters. Martinus Nijhoff/Dr W. Junk Publishers: Boston, 497 pp.

Thurman, E.M.; Goolsby, D.A.; MeyerR, M.T.; and Kolpin, D.W., 1991, Herbicides in surface waters of the midwestern United States: The effect of spring flush. Environ. Sci. Technol., 25:1794

Tilzer, M.M., 1987, Environmental and physiological control of phytoplankton productivity in large lakes. In Tilzer, M.M. and Serruya, C. eds. Large Lakes, Springer-Verlag: Berlin, 339-367.

Torn, M.S., Trumbore, S.E., Chadwick, O.A., and others, 1997, Mineral control of soil organic storage and turnover. Nature, 389, 170-173.

Trumbore, S.E., 1993, Comparison of carbon dynamics in tropical and temperate soils using radiocarbon measurements. Global Biogeochemical Cycles, 7, 275-290.

Vogel, J.S.; Southon, J.R.; Nelson, D.E., 1987, Catalyst and binder effects in the use of filimentous graphite in AMS. Nuclear Instruments and Methods in Physics Research., B29, 50-56.

Wassenaar, L. Aravena, R., Fritz, P. Baker, J., 1990, Isotopic composition $\left({ }^{13} \mathrm{C},{ }^{14} \mathrm{C},{ }^{2} \mathrm{H}\right)$ and geochemistry of aquatic humic substances from groundwater. Org. Geochem., 15, 383-396.

Wedin, D.A., Tiezin, L.L., Dewey, B., Pastor, J., 1995, Carbon isotope dynamics during grass decomposition and soil organic matter formation. Ecology, 76, 1383-1392.

Wershaw, R.L., Leenheer, J.A., Kennedy, K.R., Noyes, T.I., 1996, Use of ${ }^{13}$ C NMR and FTIR for elucidation of degradation pathways during natural litter decomposition and composting. 1. Early stage leaf degradation. Soil Sci., 161, 667-679.

Williams, P.M., Roberston, K.J., Soutar, A. et al., 1992, Isotopic signatures $\left({ }^{13} \mathrm{C},{ }^{14} \mathrm{C}\right.$, ${ }^{15} \mathrm{~N}$ ) as tracers of sources and cycling of soluble and particulate organic matter in the Santa Monica Basin, California. Prog. Oceanogr., 30, 253-290. 


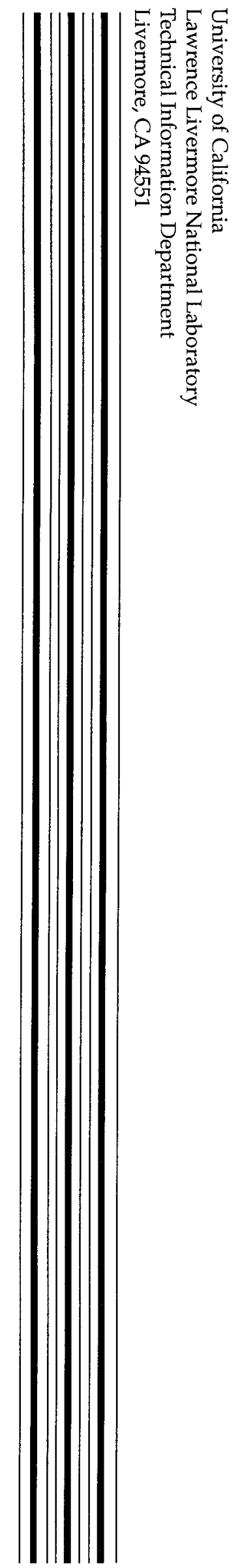

